\title{
The Judicial Restraint of the Warren Court (and Why it Matters)
}

\author{
REBECCA E. ZIETLOW*
}

"[W]here [Congress] keeps within its sphere and violates no express constitutional limitation it has been the rule of this Court, going back almost to the founding days of the Republic, not to interfere."1

In politics and in academia, the Warren Court is virtually synonymous with the term "judicial activism." The many "activist" rulings of the Warren Court expanding individual rights and the jurisdiction of federal courts are the paradigmatic example of courts protecting the rights of minorities. Yet this Article points out another side of the Warren Court's jurisprudence-its restraint towards congressional power, especially when Congress used that power to protect the rights of minorities in our society. It considers the role of a particular set of rights: rights of belongingthose rights that promote an inclusive vision of who belongs to the national community and facilitate equal membership in that community. In a series of landmark decisions articulating its deference to Congress, the Warren Court invited and encouraged popular constitutionalism, enabling members of Congress to use their own judgment in defining and protecting rights of belonging. The Article argues that the strongest contribution that the Warren Court made to expanding equality rights was not its judicial activism in protecting those rights, but its restraint in allowing Congress to protect those rights.

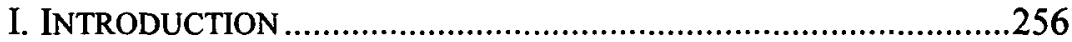

II. JUDICIAL ACTIVISM AND RIGHTS OF BELONGING ....................262

A. The Terms of the Debate ................................................263

B. Judicial Activism's Impact on Congress's Enduring Role as a Protector of Rights of Belonging.........................265

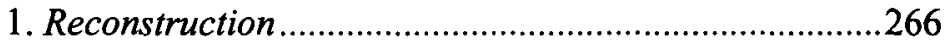

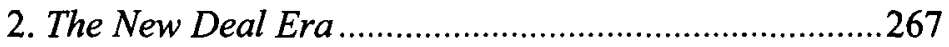

III. THE JUDICIAL ACTIVISM OF THE WARREN COURT ..................269

A. The Warren Court's Activism...........................................270

* Charles W. Formoff Professor of Law and Values, University of Toledo College of Law. Thanks to Michelle Adams, Mark Graber, Rachel Godsil, Leslie Goldstein, W. David Koeninger, Bill Richman, Joseph Slater, and Michael Solimine for their comments on earlier drafts. I hope I have done justice to their thoughtful critiques. I presented a version of this essay to the 2006 annual meeting of the Law and Society Association and the 2007 annual meeting of the Midwest Political Science Association, and very much benefited from the exchange with participants in those workshops. Thanks also to my excellent research assistants, Drew Maunz and Trey Pauley.

${ }^{1}$ Katzenbach v. McClung, 379 U.S. 294, 305 (1964). 
B. Criticism of the Warren Court's Activism..........................271

C. Praise of the Warren Court's Activism ..............................273

IV. THE JUDICIAL RESTRAINT OF THE WARREN COURT .................274

A. Baseline-Rational Basis Review.......................................275

B. Commerce Clause.........................................................227

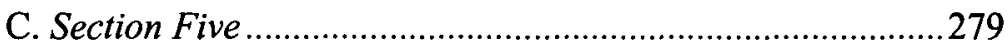

D. Thirteenth Amendment .....................................................284

E. Congress in the Second Reconstruction ............................285

V. THE ACTIVISM OF THE REHNQUIST COURT ............................287

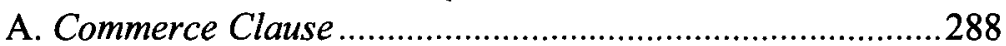

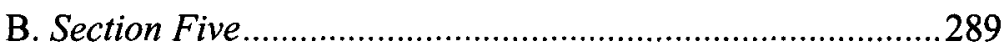

C. Sovereign Immunity ......................................................291

VI. THE IMPORTANCE OF CONGRESSIONAL AUTONOMY ...............292

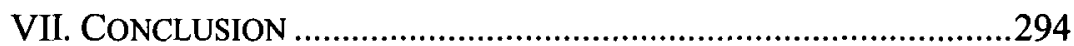

\section{INTRODUCTION}

In recent years, opposing "activist judges" has become something of a mantra for conservative politicians. Those on the political right most often use the term "judicial activism" to refer to liberal judges striking down their legislation. At the same time, constitutional scholars have engaged in a parallel debate over the value of "popular constitutionalism," that is, constitutional interpretation outside of the courts. ${ }^{2}$ Advocates of popular constitutionalism question the primacy of judicial review over constitutional interpretation by the political branches, ${ }^{3}$ while its critics maintain that judicial review is necessary for stable and principled constitutional interpretation. ${ }^{4}$ These debates raise the age-old question of the appropriate relationship between courts and legislatures with regard to individual rights. Critics of popular constitutionalism maintain that an active judiciary is necessary for the adequate protection of minority rights because equality norms need protection from majority rule, ${ }^{5}$ and with few exceptions, even

2 See generally Larry D. Kramer, Popular Constitutionalism, circa 2004, 92 CAL. L. REV. 959 (2004) (describing that debate).

3 See, e.g., LARRY D. KRAMER, THE PEOPle Themselves: Popular Constitutionalism AND Judiclal Review (2004); Robert C. Post \& Reva B. Siegel, Legislative Constitutionalism and Section Five Power: Policentric Interpretation of the Family and Medical Leave Act, 112 YALE L.J. 1943, 1995 n.158 (2003).

${ }^{4}$ See, e.g., Larry Alexander \& Frederick Shauer, Defending Judicial Supremacy: A Reply, 17 CONST. COMMENT. 455 (2000); Erwin Chemerinsky, In Defense of Judicial Review: A Reply to Professor Kramer, 92 CAL. L. REV. 1013 (2004).

5 See Chemerinsky, supra note 4, at 1025. 
the staunchest proponents of popular constitutionalism agree. ${ }^{6}$ These scholars support judicial activism as a means of protecting minority rights.

The many "activist" rulings of the Warren Court expanding individual rights and the jurisdiction of federal courts are the paradigmatic example of courts protecting the rights of minorities. Indeed, in academia and in politics, the Warren Court is still synonymous with judicial activism. ${ }^{7}$ However, a closer examination of the Warren Court's legacy reveals that that Court's approach to equality rights was considerably more complex than this paradigm suggests. There is another side to the Warren Court legacy-that Court's deference towards congressional power. In a series of landmark decisions articulating its deference to Congress, the Warren Court invited and encouraged popular constitutionalism, enabling members of Congress to use their own judgment in defining and protecting minority rights. ${ }^{8}$ Indeed, the strongest contribution that the Warren Court made to expanding equality rights was not its judicial activism in protecting those rights, but its restraint in allowing Congress to protect those rights.

The Warren Court Era saw a marked expansion of "rights of belonging," those rights that promote an inclusive vision of who belongs to the national community and facilitate equal membership in that community. ${ }^{9}$ Based in

${ }^{6}$ See, e.g., Kramer, supra note 2, at 997 (arguing that supporters of popular constitutionalism should not be too cavalier about the fate of individual rights in a democratic system); Robert C. Post \& Reva B. Siegel, Popular Constitutionalism, Departmentalism, and Judicial Supremacy, 92 CAL. L. REV. 1027, 1038 (2004) ("Yet to allow the political judgment of the Constitution to dictate constitutional law is to risk undermining the stability and reliability of the very constitutional rights that may express and protect our values."). But see MARK TUSHNET, TAKING THE CONSTITUTION AWAY FROM THE COURTS 154-76 (1999) (arguing against judicial review).

7 But see THOMAs M. KECK, THE MOST ACTIVIST SUPREME COURT IN History: THE ROAD TO MODERN JUDICIAL CONSERVATISM 14 (2004) (positing conversations about the Court too often equate judicial activism with the Warren Court); LUCAS A. POWE, JR., THE WARREN COURT AND AMERICAN Politics (2000) (arguing that the Warren Court's rulings were consistent with the politics of its time). For an interesting attempt to differentiate the activism of the Warren Court from that of the Rehnquist Court, see Jack M. Balkin \& Sanford Levinson, Understanding the Constitutional Revolution, 87 VA. L. REV. 1045 (2001).

${ }^{8}$ See Robert C. Post \& Reva B. Siegel, Equal Protection by Law: Federal Antidiscrimination Legislation After Morrison and Kimel, 110 YALE L.J. 441, 495 (2000) [hereinafter Post \& Siegel, Equal Protection].

${ }^{9}$ See Denise C. Morgan \& Rebecca E. Zietlow, The New Parity Debate: Congress and Rights of Belonging, 73 U. CIN. L. REV. 1347, 1392 (2005) (introducing the concept of rights of belonging). For a more detailed discussion of the meaning and scope of rights of belonging, see REBECCA E. ZIETLOW, ENFORCING EQUALITY: CONGRESS, THE CONSTITUTION, AND THE PROTECTION OF INDIVIDUAL RIGHTS 6-8 (2006) [hereinafter ZIETLOW, ENFORCING EQUALITY]. The term "belonging" is most closely associated with Professor Kenneth Karst, who has written extensively about equal citizenship. See 
equality, rights of belonging help to define and expand access to the community in which we live by removing barriers to participation in that community. ${ }^{10}$ Both critics and supporters of the Warren Court often attribute the expansion of those rights to that Court, whether condemning the Court for illegitimately imposing its own will on the democratic process or praising the Justices of the Warren Court as "countermajoritarian heroes" protecting rights of "discrete and insular" minorities. " Yet while the Warren Court certainly was protective of rights of belonging, the Warren Court's restraint towards Congress enabled that body to be equally protective of those rights. Indeed, from the 1964 Civil Rights Act to the 1994 Violence Against Women Act, Congress gave those rights more protections than did federal courts.

Warren Court decisions such as Brown v. Board of Education ${ }^{12}$ provide support for the argument that judicial activism is necessary for the adequate protection of rights of belonging. Inspired by the Warren Court, many scholars have argued that an active judiciary is necessary for the adequate

Kenneth L. Karst, Belonging to America: EQual Citizenship and the CONSTITUTION (1989).

${ }^{10}$ For example, civil rights legislation opens access to employment, education, and other opportunities, and the right to join a union empowers workers to participate in their workplace and in the political arena. In contrast, liberty interests, like the right to family autonomy and freedom of speech, in and of themselves are not rights of belonging. However, liberty-based rights can implicate equality-based rights. For example, the right to marry is a liberty interest, rooted in individual autonomy, but it becomes an equality interest when it is denied to one group of people based on immutable characteristics. See Loving v. Virginia, 388 U.S. 1 (1967). This Article does not attempt to define all rights of belonging, nor would it be possible to do so. The focus of this Article is on the process of definition-indeed, participating in defining rights of belonging is itself an act of belonging. See ZIETLOW, ENFORCING EQUALITY, supra note 9, at 167-68.

11 See, e.g., AleXander M. Bickel, The Least Dangerous Branch: The SuPREME COURT AT THE BAR OF POLITICS, 16-23 (1962) (same); LEARNED HAND, THE BILl OF RIGHTS: THE OLIVER WENDELL HOLMES LECTURES 73-74 (1958) (criticizing the Warren Court); Philip B. Kurland, The Supreme Court 1963 Term, Foreword: "Equal in Origin and Equal in Title to the Legislative and Executive Branches of the Government," 78 HaRv. L. REV. 143 (1964) (same); Owen Fiss, A Life Lived Twice, 100 Yale L.J. 1117,1118 (1991) (praising the Warren Court); Michael J. Gerhardt, The Rhetoric of Judicial Critique: From Judicial Restraint to the Virtual Bill of Rights, 10 WM. \& MARY BILL RTS. J. 585, 618 (2002) (same); David Luban, The Warren Court and the Concept of a Right, 34 HARV. C.R.-C.L. L. REV. 7,7 (1999) (same). See also Michael J. Klarman, Rethinking the Civil Rights and Civil Liberties Revolutions, 82 VA. L. REV. 1, 19 (1996) (pointing out that many scholars think Brown proves that courts are "countermajoritarian heroics" who protect minority rights).

12347 U.S. 483 (1954). 
protection the rights of "discrete and insular minorities."13 Yet the little known and understood truth is that throughout the history of our country, proponents of rights of belonging have been more successful with politics than with litigation. ${ }^{14}$ Judicial restraint, not judicial activism, has always been necessary for the healthy development of rights of belonging in this country. ${ }^{15}$ Not only has the Court rarely acted to protect rights of belonging as the Warren Court did, but it has also rarely allowed congressional efforts to protect those rights. ${ }^{16}$ Understanding this, prior to the Warren Court Era, progressives consistently advocated for judicial restraint, not judicial activism. Since the Warren Court Era, the Supreme Court has returned to its activist ways in its relationship to Congress, striking down congressional efforts to define and protect rights of belonging. ${ }^{17}$

In contrast to the Warren Court's deference to congressional power, the Rehnquist Court was considerably more "activist" in its approach to that coordinate body. The Rehnquist Court struck down a record thirty-three acts of Congress from 1995 to 2003, compared to only seventeen during the most activist period of the Warren Court. ${ }^{18}$ Moreover, while the Warren Court

${ }^{13}$ A recent Lexis search uncovered 506 law review articles written in the past twenty years advocating the proposition that courts should protect minorities against the will of the majority. For just a few of the many prominent scholars supporting this view, see JUDITH A. BAER, EQUALITY UNDER THE CONSTITUTION: RECLAIMING THE FoURTEENTH AMENDMENT 281 (1983); Charles L. BLACK, JR., A NeW BiRTH OF FREEDOM: HUMAN RIGHTS, NAMED AND UNNAMED 125 (1997); KARST, supra note 9, at 9. The term "discrete and insular minorities" is borrowed from Justice Stone's influential footnote four in United States v. Carolene Products Co., 304 U.S. 144, 153 n.4 (1938).

${ }^{14}$ For a detailed account of this phenomenon, see ZIETLOW, ENFORCING EQUALITY, supra note 9, at $\mathrm{Ch}$. 3-5 (discussing the historical dynamics of congressional protection of rights of belonging during Reconstruction, the New Deal, and the "Second Reconstruction" of the 1960s).

${ }^{15} \mathrm{Id}$.

16 Indeed, what most distinguishes the Warren Court may be the extent to which the political process largely coincided with that particular Court's value preferences. See generally PowE, supra note 7 . I owe this thought to Michelle Adams.

17 See Ruth Colker \& James J. Brudney, Dissing Congress, 100 MICH. L. REv. 80 (2001).

18 According to Thomas Keck, that period extended from 1962 to 1969. See KECK, supra note 7, at 40 (2004). From 1995 to 2003, the Court struck down an average of 3.67 federal statutes per year, more than double the average of the Warren Court. Id. The earlier Rehnquist Court was considerably less activist, striking down only seven federal statutes from 1986 to 1994 , an average of 0.78 per year, making a total average of 2.35 per year. Id. The Warren Court struck down an average of 1.64 federal statutes per year over its entire tenure, with an average of 2.29 per year during its most activist period, 1963-1969. Id. Of course, it is possible that the Rehnquist Court simply had more opportunities to strike down federal statutes because there were more unconstitutional federal laws to strike down. See Anna Harvey \& Barry Friedman, Pulling Punches: 
invalidated only federal statutes "of little or no significance,"19 many of the federal statutes invalidated by the Rehnquist Court enjoyed strong bipartisan support. ${ }^{20}$ Most importantly, while the Warren Court was most deferential to Congress's power to define and protect rights of belonging, the Rehnquist Court imposed its most rigorous scrutiny on such statutes. ${ }^{21}$ Yet, as the Warren Court understood, when minorities win in the political process, those victories are entitled to the maximum amount of deference by the countermajoritarian courts. By definition repeat losers in the majoritarian political process, discrete and insular minorities only achieve victories in that process with intense effort and years of activism. ${ }^{22}$ Their successful struggle to obtain legislation that protects their rights deserves respect from the courts in the form of deference to that legislation.

Underlying the debate over judicial activism is the question of what role values should play in shaping the law, and which branch is best suited to determine those values. Responding to "activist" decisions striking down restrictions on abortion and gay marriage, political conservatives argue that unaccountable judges should not be allowed to shape our values. ${ }^{23}$ Put on

Congressional Constraints on the Supreme Court's Constitutional Rulings, 1987-2000, 31 LEGIS. STUDIES Q. 533 (2006).

${ }^{19}$ L.A. Powe, Jr., The Politics of American Judicial Review: Reflections on the Marshall, Warren, and Rehnquist Courts, 38 WAKE FOREST L. REV. 697, 717 (2003).

${ }^{20}$ See Mark A. Graber, Constructing Judicial Review, 8 ANN. Rev. POL. SCI. 444 (2005). The most notable example is the Religious Freedom Restoration Act, invalidated in City of Boerne v. Flores, 521 U.S. 507 (1997), which was approved virtually unanimously; see also ZIETLOW, ENFORCING EQUALITY, supra note 9, at 2-5.

21 The Rehnquist Court applied heightened scrutiny to Commerce Clause-based civil rights legislation in United States v. Morrison, 529 U.S. 598 (2000), and a strict scrutinylike "congruence and proportionality" test to legislation enforcing the Fourteenth Amendment. See City of Boerne, 521 U.S. at 520. Along with its decision in Morrison invalidating the civil rights provision in the Violence Against Women Act, the Court also struck down provisions of the Americans with Disabilities Act and the Age Discrimination in Employment Act. See Bd. of Trs. of Univ. of Ala. v. Garrett, 531 U.S. 356, 360 (2001); Kimel v. Fla. Bd. of Regents, 528 U.S. 62, 67 (2000). See also Appendix B. For an argument that the Rehnquist Court targeted certain types of civil rights legislation, see Jed Rubenfeld, The Anti-Antidiscrimination Agenda, 111 YALE L.J. 1141 (2002).

${ }^{22}$ For example, the 1964 Civil Rights Act and the 1965 Voting Rights Act were congressional responses to years of struggle by civil rights activists. See Rebecca E. Zietlow, To Secure These Rights: Congress, Courts, and the 1964 Civil Rights Act, 57 RUTGERS L. REV. 945, 957-61 (2005).

${ }^{23}$ See Karen Branch-Brioso \& Jo Mannies, D.C. Marchers Demand an End to Abortions, St. LouIs Post-DisPaTch, Jan. 23, 2003, at A1 (activist Mary Marchmeier says Roe v. Wade "was brought to you by a bunch of elitist judges who decided to usurp the Legislature's authority"); Tim Poor, Ashcroft Denounces 'Judicial Despotism' by Federal Courts, ST. LouIs Post-DisPatch, Mar. 6, 1997, at 5A; Mark Silva, Bush Backs 
the defensive, supporters of rights of belonging find themselves reflexively defending courts as protectors of our values. ${ }^{24}$ Yet that approach is not only counter-historical, there are strong institutional and policy reasons why confining debates over values to the judicial process may have a harmful effect on rights of belonging.

Legislation creating rights of belonging is likely to be more effective than court rulings expanding those rights because the transparency and accountability of the political process are more likely to foster popular acceptance. Rights of belonging are more likely to flourish if they are part of the ongoing political dialogue over values in our society. For those who have historically lacked power in our society, participation in the political process itself is also an act of belonging. An open dialogue about the meaning and extent of rights of belonging is healthy for our civic society because it provides a mechanism for dialogue about our fundamental values. Judicial activism creates the danger of stifling that debate. ${ }^{25}$ Thus, judicial restraint, and not judicial activism, is likely to foster the most robust rights of belonging.

Part II of this Article discusses the terms of the debate, defining judicial activism and explaining its historical relationship to rights of belonging. Part III summarizes the activism of the Warren Court in protecting individual rights, and Part IV correspondingly illustrates that Court's restraint when Congress acted to protect those rights. Part V contrasts the activism of the Rehnquist Court in restricting congressional autonomy to protect rights of belonging to the restraint of the Warren Court. Finally, Part VI discusses the institutional reasons behind the importance of congressional autonomy to protect rights of belonging. The Rehnquist Court's activism has led many constitutional law scholars to reconsider their position on judicial review. ${ }^{26}$ Those of us who support the expansion of rights of belonging should advocate judicial restraint.

Amendment on Marriage, CHI. TRIB., June 6, 2006, $\S 1$, at 4 (quoting Bush as saying "[a]n amendment to the Constitution is necessary because activist courts have left our nation with no other choice").

24 See Alliance For Justice, http://afj.org (last visited Apr. 2, 2008); National Organization for Women, http://now.org (last visited Apr. 2, 2008).

25 See Mary AnN Glendon, Rights Talk: The Impoverishment of Political DISCOURSE 6 (1991); TUSHNET, supra note 6, at 169.

${ }^{26} C f$., TUSHNET, supra note 6, at 154-176 (arguing against judicial review); Kramer, supra note 2 (supporting the concept of "popular constitutionalism" or constitutional interpretation outside of the courts); Chemerinsky, supra note 4, at 1018-22 (arguing that judicial review is necessary to protect minority rights); Post \& Siegel, supra note 6, at 1038 ("Yet to allow the political judgment of the Constitution to dictate constitutional law is to risk undermining the stability and reliability of the very constitutional rights that may express and protect our values."). 


\section{JUDICIAL ACTIVISM AND RIGHTS OF BELONGING}

In today's political debate, the term "judicial activism" has become so overused as to be practically meaningless. ${ }^{27}$ Politicians and pundits seem to invoke the term whenever they disagree with a court's decision. ${ }^{28}$ Hence, it is important to define the term at the outset. Black's Law Dictionary defines "judicial activism" as "[a] philosophy of judicial decision-making whereby judges allow their personal views about public policy, among other factors, to guide their decisions, usually with the suggestion that adherents of this philosophy tend to find constitutional violations and are willing to ignore precedent."29 As Ernest Young recently observed, "judicial activism" "involve[s] a refusal by the court deciding a particular case to defer to other sorts of authority at the expense of its own independent judgment about the correct legal outcome." 30 While these definitions suggest that there are a variety of judicial practices that may amount to "judicial activism," my primary focus is on the relationship between courts and legislatures, and in particular, on the relationship between the Supreme Court and Congress.

While judicial activism is problematic because the Court intrudes on the democratic process, proponents of rights of belonging often argue that activism is necessary to protect minorities against that process. ${ }^{31}$ Yet the widely held view of courts as protectors of minorities is a relatively recent phenomenon. With the exception of the Warren Court, throughout our history, activist courts have been considerably more likely to rule against rights of belonging, not to uphold them. ${ }^{32}$ Legislatures, not courts, have historically provided the most protection for those rights.

27 See Ernest A. Young, Judicial Activism and Conservative Politics, 73 U. CoLo. L. REV. 1139, 1143 (2002).

28 Probably the most ironic use of the term was when members of Congress accused the federal courts of judicial activism for failing to hear the appeal of Terri Schiavo's parents from the state court decision to allow doctors to terminate life sustaining measures. See Edward A. Hartnett, Congress Clears its Throat, 22 Const. COMMENT. 553,555 ("For some, the term 'judicial activism' is an empty epithet, meaning little more than that the one who hurls the term disagrees with a particular decision or line of decisions.").

29 BLACK'S LAW DiCTIONARY 862 (8th ed. 2004). See also Young, supra note 27, at 1144.

30 Young, supra note 27, at 1145.

31 See, e.g., Chemerinsky, supra note 4, at 1014.

32 See infra notes 47-64 and accompanying text. 


\section{A. The Terms of the Debate}

Put simply, legislatures are elected by the people and therefore accountable to the people for their policy decisions. Federal judges are not elected, and their lifetime job protection makes them less accountable to the people. Recently, political scientists have suggested that this account is overly simplistic because "[j]udicial review is established and maintained by elected officials." 33 Nevertheless, whenever a judge overrules the decision of a legislature, he or she potentially subjects herself to charges of judicial activism. As Alexander Bickel, a long-time critic of the Warren Court, described it, the "counter-majoritarian difficulty" potentially undermines the legitimacy of federal courts when they second-guess legislatures. ${ }^{34}$ Moreover, when the Supreme Court overturns an act of Congress, a co-equal branch, that action raises the additional concern about the proper balance of powers between the federal judiciary and the legislature.

Because the federal government is one of limited powers, there are two types of Supreme Court decisions striking down federal legislation -those decisions finding the legislation beyond the inherent, or internal limits of Congress, and those holding that the legislation violates some external constitutional limit. In the first group, the Court holds that Congress lacked the power to legislate to begin with, which amounts to a facial invalidation of a statute..$^{35}$ In the second group, the Court may find that although Congress had the inherent power to legislate, a particular application of the law violates another provision of the Constitution. ${ }^{36}$ While both types of decisions are arguably examples of judicial activism, the first group is more

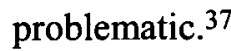

Whenever the Court holds that a federal statute is beyond the inherent powers of Congress, it is second-guessing Congress's determination that the

33 Graber, supra note 20 , at 427.

34 See BICKEL, supra note 11, at 16-23; see also Young, supra note 27, at 1146. It is debatable whether courts actually behave in a counter-majoritarian fashion. See generally Robert A. Dahl, Decision-Making in a Democracy: The Supreme Court as a National Policy-maker, 50 EMORY L.J. 563 (2001); Barry Friedman, Mediated Popular Constitutionalism, 101 MICH. L. REV. 2596 (2003). Nonetheless, the fact remains that political officials are elected by the people, and judges are not.

35 For example, the Court may find that a statute falls beyond Congress's Commerce power. See, e.g., United States v. Morrison, 529 U.S. 598, 619 (2000).

36 For example, the Court may find that a criminal law violates the Fifth Amendment. See, e.g., United States v. Romano, 382 U.S. 136, 138 (1965).

37 Jesse Choper makes a similar argument, that judicial review of the political branches is generally not justified unless it is on behalf of protecting individual rights. See Jesse H. ChOPER, Judicial ReVIEW and the National Political Process: A FUNCTIONAL RECONSIDERATION OF THE ROLE OF THE SUPREME COURT 59-60 (1980). 
statute was constitutional, and correspondingly expanding the power of the Court at the expense of Congress. ${ }^{38}$ While both types of rulings involve the exercise of judicial review, arguably only the first group entails an assertion of judicial supremacy ${ }^{39}$ because the Court is second-guessing the presumed judgment of members of Congress that they had the constitutional power to act. Courts are better suited for the second type of determination, considering the constitutionality of a particular application of a statute, since applying the law to a particular set of facts is what courts are best qualified to do. While either type of ruling enables courts to indulge in policy preferences and limit the means used by Congress, only the first type completely disables Congress from pursuing the ends that members of that body want to achieve. ${ }^{40}$

The flipside of judicial activism is "judicial restraint." "Restrained" judges defer to the expertise of the political branches. As Thomas Keck observes, "if judicial restraint means anything in the context of the long conservative critique of the Warren Court and its legacy, it must mean a relative unwillingness to declare constitutional limitations on government."41 Judges exercising judicial restraint will be hesitant to overturn decisions made by the political branches because they are cognizant of their institutional limitations, including their lack of accountability. ${ }^{42}$ Restrained judges recognize the institutional advantages of the political branches when they create law, and respect their authority to do so. Judicial restraint is thus "rooted in a majoritarian conception of American democracy." 43 Hence, judges should use judicial restraint whenever possible. ${ }^{44}$

38 See CHOPER, supra note 37, at 36; Hartnett, supra note 28, at 557 (pointing out the "presumption that Acts of Congress are constitutional").

39 See Keith E. Whittington, Extrajudicial Constitutional Interpretation: Three Objections and Responses, 80 N.C. L. REV. 773, 780 (2002) (distinguishing between "judicial review" and "judicial supremacy"). here.

40 Thanks to Michelle Adams and Mark Graber for helping me to clarify my point

41 KECK, supra note 7, at 1.

42 See, e.g., City of Cleburne v. Cleburne Living Ctr., Inc., 473 U.S. 432, 460 (1985) (Marshall, J., concurring in the judgment in part and dissenting in part).

43 KECK, supra note 7, at 21.

44 The standard response to my call for judicial restraint is that when the Court strikes down a legislative act, it acts with the authority to enforce the people's will embodied in the Constitution. See Young, supra note 27, at 1147 (citing JOHN HART ELY, DEMOCRACY AND DISTRUST: A THEORY OF JUDICIAL REVIEW 8-9 (1980)). However, this argument is less persuasive when one considers that Congress is also interpreting the Constitution when it legislates, especially when it legislates to protect fundamental rights like rights of belonging. See ZIETLOW, ENFORCING EQUALITY, supra note 9, at 9-10; see generally KEITH E. WhITTINGTON, CONSTITUTIONAL CONSTRUCTION: DIVIDED POWERS 
Of course, this discussion of judicial activism and restraint is arguably beside the point to those who are most concerned about rights of minorities. "Sure," they argue, "ideally both courts and Congress act to protect rights of belonging, ${ }^{45}$ and proponents of those rights should only resort to courts when they fail in the political process. But sometimes it is necessary for judges to intervene in that process in order to insure that it works, and often this intervention is needed on behalf of minorities." 46 However, while this theory makes sense in the abstract, it is not borne out by our history. ${ }^{47}$ Minorities often lose in courts, and they tend to win in the political process far more often than this standard paradigm suggests. Moreover, with the exception of the Warren Court, activist courts have often refused to defer to the legislative victories of minorities.

\section{B. Judicial Activism's Impact on Congress's Enduring Role as a Protector of Rights of Belonging}

Ever since Reconstruction, members of Congress have acted repeatedly to protect rights of belonging, playing a leading role in historical periods marked by great expansions of rights of belonging, including Reconstruction, the New Deal, and the Second Reconstruction of the 1960s. ${ }^{48}$ Congress's rights-generating role is mandated by the Constitution, enshrined not only in the enforcement clauses of the Reconstruction Amendments, but in every single subsequent constitutional amendment that expands individual rights. ${ }^{49}$ However, the Supreme Court has often

AND CONSTITUTIONAL MEANING (1999). see ZIETLOW, ENFORCING EQUALITY, supra note 9, at 9-10.

45 Indeed, effective protection of those rights probably requires all branches acting in concert. See generally Gerald N. ROSENBERG, THE Hollow Hope: CAN COURTS BRING ABOUt SoClal ChANGE? (1991).

46 See United States v. Carolene Prods. Co., 304 U.S. 144, 152 n.4 (1938); ElY, supra note 44 , at $7-8$.

47 See Klarman, supra note 11 , at 7.

48 Of course, Congress has also often remained inactive in the face of societal injustice. The most notable example of this inaction is Congress's failure to enact legislation to address race discrimination in the Jim Crow Era from the end of Reconstruction until the late 1950s. For a detailed discussion of this period, see MICHAEL J. Klarman, From Jim Crow to Civil Rights (2004). For an in-depth discussion of congressional action and inaction during this period, see ZIETLOW, ENFORCING EQUALITY, supra note 9, at chs. 3-6 (discussing the historical dynamics of congressional protection of rights of belonging during Reconstruction, the New Deal, and the Second Reconstruction of the 1960s).

${ }^{49}$ See U.S. CONST. amends. XIII (abolishing slavery and giving Congress the power to "enforce this article by appropriate legislation"), XIV, XV (prohibiting the federal government and states from denying the right to vote on account of race and giving 
responded negatively to congressional efforts to protect rights of belonging, narrowly reading congressional power to protect those rights and restricting the scope of such legislation. ${ }^{50}$ Historically, what is at stake in the debate over judicial activism is not just the proper relationship between courts and legislatures, but the scope of our rights to belong to the national community.

\section{Reconstruction}

Members of the Reconstruction Congress enacted the Thirteenth, Fourteenth, and Fifteenth Amendments to end slavery and protect the rights of freed slaves and other persons within their jurisdiction. All of these Amendments contained enforcement provisions empowering Congress to protect those rights. The enforcement clauses marked a major constitutional change. Before those, there was no provision of the Constitution that empowered Congress to protect rights of belonging, or any other individual rights. ${ }^{51}$ Indeed, empowering Congress to protect rights of belonging was central to the mission of the Thirty-Ninth Congress and the raison d'être of the Fourteenth Amendment. ${ }^{52}$ Members of the Reconstruction Congress viewed the Supreme Court as an agent of the Slave Power. The pro-slavery

Congress the power to "enforce this article by appropriate legislation"), XIX (prohibiting the denial of the right to vote on account of sex and giving Congress the power to "enforce this article by appropriate legislation"), XXIII (bestowing the right to vote for the President on residents of the District of Columbia and giving Congress the power to "enforce this article by appropriate legislation"), XXIV (prohibiting the use of poll taxes as a voting qualification and giving Congress the power to "enforce this article by appropriate legislation"), XXVI (lowering the voting age to eighteen and giving Congress the power to "enforce this article by appropriate legislation").

50 Indeed, it is the Warren Court's deference to congressional power to protect rights of belonging, and not the Rehnquist Court's activism against that power, that is the historical anomaly.

51 Notwithstanding this fact, the Supreme Court upheld two fugitive slave acts as enforcement of the Fugitive Slave Clause and the property rights of slave owners. See Prigg v. Pennsylvania, 41 U.S. (16 Pet.) 539, 622 (1842); Ableman v. Booth, 62 U.S. (21 How.) 506, 526 (1858).

52 As John Bingham, the principal author of that Amendment, explained during the debate over the Amendment, "Sir, it has been the want of the Republic that there was not an express grant of power in the Constitution to enable the whole people of every State, by congressional enactment, to enforce obedience to these requirements of the Constitution." CONG. GlOBE, 39th Cong., 1st Sess. 1034 (1866). The Warren Court recognized this, noting that "the sponsors and supporters of the [Fourteenth] Amendment were primarily interested in augmenting the power of Congress, rather than the judiciary." Katzenbach v. Morgan, 384 U.S. 641, 648 n.7 (1966) (citing JACOBUS TENBROEK, THE ANTISLAVERY ORIGINS OF THE FOURTEENTH AMENDMENT 187-217 (1951) and Laurent B. Frantz, Congressional Power to Enforce the Fourteenth Amendment Against Private Acts, 73 Y ALE L.J. 1353, 1356-57 (1964)) . 
Dred Scott decision, not the anti-segregation Brown v. Board of Education, was their model of the Court's treatment of individual rights. Therefore, they saw themselves, and not the Court, as the primary enforcers of rights of belonging. ${ }^{53}$

Along with the Reconstruction Amendments, these members of Congress enacted numerous statutes protecting rights of belonging, including civil rights statutes and the Freedmen's Bureaus with their massive social programs to facilitate Reconstruction. ${ }^{54}$ After the compromise of 1876, Democrats took control of Congress and the political body turned away from protecting rights of belonging. However, well before that date, the Court had already restricted the meaning of the Fourteenth Amendment in The Slaughter-House Cases. ${ }^{55}$ In 1883, the Court issued perhaps its most important decision restricting the scope of the Reconstruction Amendments: the Civil Rights Cases, limiting Congress's power to enforce the Fourteenth Amendment to remedying state action and narrowly defining the "badges and incidents of slavery" remediable by Congress's power to enforce the Thirteenth Amendment.56 These decisions proved that members of the Reconstruction Congress had been right to distrust the Court. ${ }^{57}$

\section{The New Deal Era}

It was not until the 1960 s and the advent of the modern civil rights movement that Congress returned to protecting the rights of racial minorities. In the meantime, before and during the New Deal, Congress acted to protect the rights of belonging of workers and poor people. In the

53 See James W. Fox, Citizenship, Poverty and Federalism, 60 U. PITT. L. REV. 421, 512 (1999); Post \& Siegel, Equal Protection, supra note 8, at 507.

${ }^{54}$ See ZIETLOW, ENFORCING EQUALITY, supra note 9, at ch. 3 (discussing the historical dynamics of congressional protection of rights of belonging during Reconstruction).

5583 U.S. 36,52 (1872).

56109 U.S. 3, 24-25 (1883). As Pamela Brandwein details, in these cases the Court adopted the view of the Democratic opponents of those measures in the Reconstruction Congress. See Pamela Brandwein, Reconstructing ReCONSTRUCTION: THE SUPREME CoURT AND THE PRODUCTION OF Historical TRUTH 88 (1999). The Warren Court overturned the Court's narrow definition of the "badges and incidents of slavery" in Jones v. Mayer, 392 U.S. 409, 440 (1968). See infra notes 170-74 and accompanying text.

57 The Reconstruction Congress did expand the jurisdiction of federal courts over civil rights matters in statutes such as 42 U.S.C. $\S 1983$ and 28 U.S.C. $\S 1334$. These statutes are best explained by the fact that these members of Congress distrusted state courts even more than federal courts, and because they wanted to make every possible avenue for the vindication of civil rights. See Xi Wang, The Making of Federal Enforcement Laws, 1870-1872, 70 CHI.-KENT L. REV. 1013 (1995). 
years leading up to the New Deal, workers had repeatedly gained rights in the legislative process only to have federal and state courts invalidate their gains as violating the common law "right to contract," and enjoining their right to strike as intruding on their employers" "property rights." 58 Rather than turning to the courts to enforce their rights, during this era, as during the Reconstruction Era, reformers viewed courts as an obstacle to achieving social reforms. One of their principle legislative victories was the 1932 Norris-LaGuardia Act, which restricted federal jurisdiction over labor relations in order to stifle the judicial activism those courts were using against workers and their right to organize. 59

During the time of the New Deal, Congress enacted the Wagner Act, creating a statutory right for workers to organize into a union and engage in collective bargaining, protecting other workers' rights, including the right to a minimum wage, and creating an economic safety net for workers. ${ }^{60}$ When enacting these measures, members of Congress championed a constitutional vision that centered on individual freedom and the ideology of social citizenship. ${ }^{61}$ After its flurry of activity during the New Deal, Congress was never as pro-labor again, enacting the pro-business Taft Hartley Act only twelve years later. As during Reconstruction, however, the Court was considerably more influential than Congress in restricting the scope of workers' rights, upholding the Wagner Act but issuing numerous rulings reducing the effectiveness of its protections. ${ }^{62}$ Exercising popular constitutionalism, New Deal politicians, not judges, brought about the greatest expansion of rights of belonging since the Reconstruction Era, despite the judicial activism restricting the scope of those rights.

${ }^{58} \mathrm{Id}$. at $1030-33$.

${ }^{59} \mathrm{See}$ ZIETLOW, ENFORCING EQUALITY, supra note 9, at 71.

60 See, e.g., National Labor Relations Act, ch. 372, 49 Stat. 449 (1935) (codified as amended at 29 U.S.C. $\S \S 151-166$ (2000)); Fair Labor Standards Act, ch. 676, 52 Stat. 1060 (1938) (codified as amended at 29 U.S.C. $\$ \S 201-219$ (2000)); Social Security Act, ch. 531, 49 Stat. 620 (1935). The Wagner Act established a worker's statutory right to organize into unions and bargain collectively with employers. The Act brought about a marked increase in union membership, providing workers with a source of economic empowerment, a source of community, and political empowerment, and contributed to the nascent civil rights movement. The Wagner Act had its weaknesses, most notably excluding the predominantly African-American domestic and agricultural workers in order to limit the opposition of Southem Democrats. See ZIETLOW, ENFORCING EQUALITY, supra note 9, at 93-95.

${ }^{61}$ See ZIETLOW, ENFORCING EQUality, supra note 9, at ch. 4 (discussing the historical dynamics of congressional passage of the National Labor Relations Act); William E. Forbath, Caste, Class and Equal Citizenship, 98 MiCH. L. REV. 1,4 (1999).

62 See James Gray Pope, How American Workers Lost the Right to Strike, and Other Tales, 103 Mich. L. REV. 518, 524 (2004). 
As a result of the Court's history of restricting Congress's power to protect rights of belonging, progressives in the first half of the twentieth century saw judicial activism as anathema. New Deal Era progressives on the Warren Court such as Justices Hugo Black and Felix Frankfurter became the leading opponents of that Court's activism. ${ }^{63}$ While those opponents of judicial activism would dissent in a number of "activist" Warren Court cases, ${ }^{64}$ they also influenced the Warren Court as it issued numerous rulings exercising restraint and upholding congressional power to create new rights of belonging during the Second Reconstruction of the $1960 \mathrm{~s} .65$

\section{THE JUDICIAL ACTIVISM OF THE WARREN COURT}

To be sure, in numerous cases, the Warren Court played an activist role by intervening in the political process. Perhaps the best known "activist" Warren Court case is one of its first, Brown v. Board of Education, in which the Court held that segregated elementary schools violated the Equal Protection Clause of the Fourteenth Amendment, overruling the precedent of Plessy v. Ferguson ${ }^{66}$ and challenging the segregationist way of life of millions of Americans. ${ }^{67}$ In a series of decisions following Brown, the Court struck down state-sponsored segregation in other state-run facilities, contributing to the eventual dismantling of the Jim Crow system in the South. ${ }^{68}$ Throughout the Warren Court Era, the Court often ruled in favor of civil rights and civil liberties, interpreting those civil rights and liberties expansively at the expense of legislatures, ${ }^{69}$ ordering the reconfiguration of legislative districts, ${ }^{70}$ incorporating the Bill of Rights against the states via the Due Process Clause of the Fourteenth Amendment, ${ }^{71}$ and expanding

63 See KECK, supra note 7, at 17-33.

64 See, e.g., Griswold v. Connecticut, 381 U.S. 479, 507-28 (1965) (Black, J. dissenting).

65 See infra Section IV.E.

66163 U.S. 537, 550-52 (1896).

${ }^{67}$ Brown v. Bd. of Educ., 347 U.S. 483, 495-96 (1954).

68 See, e.g., New Orleans City Park Improvement Ass'n v. Detiege, 358 U.S. 54 (1958) (parks); Gayle v. Browder, 352 U.S. 903 (1956) (buses); Holmes v. Atlanta, 350 U.S. 879 (1955) (golf courses)Mayor of Baltimore v. Dawson, 350 U.S. 877 (1955) (beaches); see also KENNETH L. KARST, BELONGING TO AMERICA: EQUAL CITIZENSHIP AND THE CONSTITUTION 58-61, 80 (1989).

69 See, e.g., Harper v. Va. State Bd. of Elections, 383 U.S. 663 (1966); Griswold v. Connecticut, 381 U.S. 479 (1965); New York Times Co. v. Sullivan, 376 U.S. 254 (1964); Griffin v. Illinois, 351 U.S. 12 (1956).

70 See Reynolds v. Sims, 377 U.S. 533, 586-87 (1964).

71 See, e.g., Gideon v. Wainwright, 372 U.S. 335, 344-45 (1963); Mapp v. Ohio, 367 U.S. 643, 656-60 (1961). 
federal jurisdiction to facilitate the vindication of those rights in federal courts. ${ }^{72}$ This activism subjected the Warren Court to virulent criticism from academics and politicians alike. It also made the Warren Court a heroic icon for an entire generation of lawyers and academics, and many of their subsequent students. ${ }^{73}$

\section{A. The Warren Court's Activism}

In the Warren Court's early years, its activism was largely limited to expanding its mandate in Brown to other government facilities and upholding the First Amendment rights of public employees accused of supporting communism. ${ }^{74}$ The Warren Court also expanded the reach of the First Amendment on behalf of civil rights activists with its landmark ruling in New York Times Co. v. Sullivan. ${ }^{75}$ The Warren Court interpreted federal rights expansively, especially those of criminal defendants, reinvigorated the Equal Protection Clause, and identified new fundamental rights such as the right to vote and the right to privacy. ${ }^{76}$ In another series of decisions, the Warren Court interpreted the Fourteenth Amendment to incorporate virtually the entire Bill of Rights against state governments. ${ }^{77}$ All of these decisions reflected the Warren Court's confidence that federal courts could competently determine the scope of individual rights, even when doing so arguably injected those courts into the realm of public policy.

Other Warren Court decisions seem at first glance to reflect a distrust of the political process. The Warren Court also enhanced the power of the federal courts through, among other things, articulating expansive tests for

72 See, e.g., Baker v. Carr, 369 U.S. 186 (1962); NAACP v. Alabama ex rel. Patterson, 357 U.S. 449 (1958); NAACP v. Alabama ex rel. Flowers, 377 U.S. 288 (1964); J.I. Case Co. v. Borak, 377 U.S. 426 (1964).

${ }^{73}$ Balkin \& Levinson, supra note 7, at 1091.

${ }^{74}$ See Powe, supra note 7, at 75-102. Due in large part to intense congressional criticism, the Court's record of upholding First Amendment rights during this period was decidedly mixed. Id. at 79 .

75376 U.S. 254 (1964). See KECK, supra note 7, at 71; Gerhardt, supra note 11, at 618.

${ }^{76}$ See Harper v. Va. State Bd. of Elections, 383 U.S. 663 (1966) (right to vote); Griswold v. Connecticut, 382 U.S. 479 (1965) (right to privacy); Brenda Swierenga, Still Newer Equal Protection: Impermissible Purpose Review in the 1984 Term, 53 U. CHI. L. REV. 1454, 1455-56 (1986) (discussing the Warren Court's Equal Protection cases).

${ }^{77}$ See, e.g., Klopfer v. North Carolina, 386 U.S. 213 (1967) (incorporating the Sixth Amendment right to a speedy and public trial); Malloy v. Hogan, 378 U.S. 1 (1964) (incorporating the Fifth Amendment right of freedom from self incrimination); Gideon v. Wainright, 372 U.S. 335 (1963) (incorporating the Sixth Amendment right to counsel); Mapp v. Ohio, 367 U.S. 643 (1961) (incorporating the Fourth Amendment right to be free from unreasonable searches and seizures). 
private rights of action, ${ }^{78}$ narrowly reading the political question doctrine and standing limitations, ${ }^{79}$ and engaging the federal courts in remedying the segregation of public schools.80 In Reynolds $v$. Sims, the Court established the "one person one vote" rule, putting into question the legitimacy of ninety percent of congressional districts and virtually all seats in state legislatures. ${ }^{81}$ Because of their impact on the political process, the reapportionment cases-Sims and its progeny-are arguably the most activist cases of the Warren Court. ${ }^{82}$ The reapportionment decisions reflect a distrust of the electoral process, especially that process in southern states, ${ }^{83}$ and lend support to the view that "the [Warren Court] justices simply did not share the scholars' faith in the democratic character of ordinary politics." 84

The Warren Court's activist decisions have been cause for both vilification and celebration. However, both opponents and supporters of the Warren Court tend to leave out that Court's legacy of restraint and respect for the legislative process, especially when that process was used as a means of popular constitutionalism.

\section{B. Criticism of the Warren Court's Activism}

From the outset, the Warren Court had its critics in both academia and the political process. Many of the Court's critics argued that the Court had exceeded its proper role within the system of separation of powers. For example, in 1958, the well-respected Judge Learned Hand gave a series of lectures at Harvard Law School in which he accused the Court of acting as if they were "Platonic Guardians." 85 Similarly, Professor Herbert Wechsler

78 See J.I. Case Co. v. Borak, 377 U.S. 426 (1964).

79 See Powell v. McCormack, 395 U.S. 486 (1969) (political question doctrine did not bar Court from ruling on disputes between members of Congress); Flast v. Cohen, 392 U.S. 83 (1968) (prudential doctrine against taxpayer standing did not bar plaintiff from challenging congressional expenditure of money on the grounds that it violated the Establishment Clause); Baker v. Carr, 369 U.S. 186 (1962) (political question doctrine did not bar Court from considering an Equal Protection challenge to state election districts).

${ }^{80}$ See, e.g., Green v. City Sch. Bd., 391 U.S. 430 (1968); Griffin v. City Sch. Bd., 377 U.S. 218 (1964).

8198 U.S. 145 (1964). See PowE, supra note 7, at 252.

82 See Powe, supra note 7, at 242-52. As Lucas Powe points out, however, Congress acted first to reform the electoral system, proposing two constitutional amendments, to abolish the poll tax in federal elections and to allow DC residents to vote for president. $I d$. at 239 .

$83 \mathrm{Id}$. at 489.

${ }^{84}$ KECK, supra note 7 , at 64 .

85 HAND, supra note 11 , at 73-74 (1958); KECK, supra note 7, at 56-57. 
criticized the Court's reasoning in Brown because he felt it could not be justified by "neutral principles." 86 In numerous works, Professor Alexander Bickel criticized the Court for making not law, but public policy. ${ }^{87}$ Probably the most virulent critic of the Court in academia was Professor Philip Kurland, who accused the Warren Court of being dogmatic, results-oriented, and even disingenuous. ${ }^{88}$

Criticism of the Warren Court also was common in the political realm. In 1956, southern members of Congress adopted the "Southern Manifesto," which charged that the Court's decision in Brown v. Board of Education was "a clear abuse of judicial power [that] climaxes a trend in the Federal judiciary undertaking to legislate, in derogation of the authority of Congress, and [encroaches] upon the reserved rights of the States and the people."89 Richard Nixon made his opposition to the Warren Court a central feature of his successful run for president in $1968 .^{90}$

In Congress, critics of the Court accused it of being pro-communist, undermining the states, and of being incompetent. Jurisdiction-stripping measures were proposed several times in response to the Court's decision upholding the First Amendment rights of those accused of supporting communism and imposing re-districting on the states. ${ }^{91}$ The Court's rulings striking down prayer in schools inspired some members of Congress to call for impeachment. ${ }^{92}$ Indeed, "Impeach Earl Warren" signs were ubiquitous throughout the South during Warren's tenure. ${ }^{93}$

None of the jurisdiction-stripping measures succeeded. Instead, Congress expanded federal jurisdiction in statutes such as the 1964 Civil Rights Act and the 1965 Voting Rights Act, indicating support for the Court's efforts. Nonetheless, political charges of judicial activism permeated the entire Warren Court Era. ${ }^{94}$

${ }^{86}$ Herbert Wechsler, Toward Neutral Principles of Constitutional Law, 73 HARV. L. Rev. 1, 24 (1959).

87 AleXander Bickel, The Supreme Court and the IDEA OF Progress 175 (1978).

${ }^{88}$ Kurland, supra note 11 , at 145.

89102 CONG. REC. H4515-16 (daily ed. Mar. 12, 1956) (statement of Rep. Smith).

90 See POWE, supra note 7, at 408-10.

${ }^{91}$ Id. at 87, 99, 130-33, 252-53.

92 See Michael Belknap, God and the Warren Court: The Quest for "A Wholesome Neutrality," 9 SETON HALL CONST. L.J. 401, 401 (1999).

93 See POWE, supra note 7, at 141.

94 Id. at 93 . 


\section{Praise of the Warren Court's Activism}

Critics of the Warren Court are not the only ones who view the Court as a paradigm of the activist Court. Many supporters of the Court extol precisely its activism, exhibiting what Laura Kalman calls a "religious and mystical" view of the Warren Court. ${ }^{95}$ For example, one of the Court's most ardent supporters, Owen Fiss, claims that although the Court drew on social movements and responded to historical circumstances, "the truth of the matter is that it was the Warren Court that spurred the great changes to follow, and inspired and protected those who sought to implement them." 96 To Fiss and other supporters of the Warren Court, the Court was heroically anti-majoritarian, championing the rights of minorities in opposition to the political bodies. ${ }^{97}$ Other scholars have argued that this view of the Warren Court is anti-historical because the Warren Court's rulings largely tracked the politics of the era. ${ }^{98}$ Yet the view of the Warren Court as the "quintessentially "activist" 99 Court persists both inside and outside the academic arena.

The widespread view of the Warren Court as an activist champion of minority rights against majoritarian tyranny is understandable given the fact that most constitutional scholars either grew up during the Warren Court Era, or were taught by constitutional law professors who grew up during that Era. To those scholars, "the philosophy of judicial restraint [championed by New Deal progressives] now seemed to justify the Court's decades-long collaboration with Jim Crow" prior to the Court's decision in Brown. ${ }^{100}$ Though the New Dealers had championed judicial restraint to end the

${ }^{95}$ Laura Kalman, The Strange Career of Legal Liberalism 4 (1996).

${ }^{96}$ Fiss, supra note 11, at 1118.

97 See, e.g., Micahel J. Gerhardt, The Rhetoric of Judicial Critique: From Judicial Restraint to the Virtual Bill of Rights, 10 WM. \& MARY BILL RTS. J. 585, 618 (2002) (pointing out the political protest that followed the Court's rulings in favor of AfricanAmericans); Bernard Schwartz, Capturing the Future: Earl Warren and Supreme Court History: The Warren Court: A Retrospective, 32 TULSA L.J. 843, 875 (1997) (finding that the "constitutional law promulgated by the Warren Court was and has been, especially for African-Americans, the civil rights movement, and criminal defendants, an unalloyed good"); see also Klarman, supra note 11, at 19 (citing scholars who argue Brown proves that courts are "countermajoritarian heroics" who protect minority rights by questioning that view).

98 See, e.g., POWE, supra note 7, at $\mathrm{xv}$ ("I hope to eschew the law professor's traditional Court-centered focus and instead place the Court where it belongs as one of the three co-equal branches of government, influencing and influenced by American politics and its cultural and intellectual currents."); Klarman, supra note 11, at 19.

${ }^{99}$ Luban, supra note 11 , at 8.

100 Balkin \& Levinson, supra note 7, at 1091. 
Lochner Era, by 1964, "judicial restraint" was no longer the call of progressives, but that of conservatives "satisfied to continue collaborating with manifest injustice."101 However, championing the Justices on the Warren Court as anti-majoritarian activists unduly discounts what is perhaps the most important legacy of the Warren Court-not its activism, but its restraint.

\section{THE JUDICIAL RESTRAINT OF THE WARREN COURT}

Notwithstanding the Warren Court's scrutiny of the electoral process in its re-apportionment cases, when it came to evaluating the actions of elected representatives, the Warren Court exhibited a markedly deferential view towards politics. The Court applied a baseline of rational basis review to all legislative acts, both state and federal, including those protecting rights of belonging. The Warren Court's opinions evaluating economic legislation and the powers of Congress are familiar to any first-year constitutional law student. Nevertheless, their import seems lost on the vast majority of observers who characterize the Warren Court as rejecting political pluralism. ${ }^{102}$ To the contrary, those decisions illustrate the fact that, in general, the Warren Court assumed that the process of legislative deliberation worked.

During a period of fifteen years, the Warren Court struck down only twenty-three federal statutes, ${ }^{103}$ and in none of those cases did the Court find that a statute exceeded the inherent power of Congress. ${ }^{104}$ Instead, the Court struck down federal statutes for the same reason it struck down state statutes-because they violated individual rights. ${ }^{105}$ Throughout its fifteen-

101 Id. at 1091; see also id. at 1088-91. By contrast, scholars such as Philip Kurland and Justice Felix Frankfurter, who matured during the Lochner era, retained their distrust of judicial activism. Id. at 1090-91; KECK, supra note 7, at 25.

102 But see Balkin \& Levinson, supra note 7, at 1092 ("The Warren Court liberals accepted the New Dealers' view that . . . Congress could do basically whatever it wished in regulating the economy."); Post \& Siegel, Equal Protection, supra note 8, at 495 (emphasizing Warren Court approval of Congress's constitutional authority to enact antidiscrimination legislation).

$103 \mathrm{KECK}$, supra note 7, at 40. By contrast, from 1995 to 2003, the Rehnquist Court struck down 33 federal statutes. Id.

104 The only case that arguably limited the inherent power of Congress was Reid $v$. Covert, in which the Court held that Congress could not use its treaty power to violate individual constitutional rights. 354 U.S. 1, 19-23 (1957). However, Reid is better understood as simply imposing external limitations on the treaty power, and is thus consistent with the other Warren Court cases that invalidated federal statutes solely on the grounds that they violated individual rights. See Appendix A.

105 See Appendix A. The Warren Court's cases invalidating state statutes are less constitutionally problematic for a number of reasons. First, the Court is not second- 
year term, the Warren Court gave Congress broad autonomy to legislate. Many Warren Court decisions reflect that Court's respect for the legislative process, especially when Congress used that process to protect rights of. belonging. The decisions allowed supporters of rights of belonging and their representatives in Congress to engage in popular constitutionalism on behalf of those rights.

\section{A. Baseline-Rational Basis Review}

In the economic realm, members of the Warren Court followed in the footsteps of their late New Deal predecessors, who had repudiated the Lochner Era of active judicial intervention that characterized the first third of the Twentieth Century. During the Lochner Era, courts had viewed economic regulation as inherently suspect and carefully scrutinized both the legislative means and ends. ${ }^{106}$ After President Roosevelt attacked this interventionist approach, the Supreme Court changed its mind and relaxed its scrutiny. ${ }^{107}$ In cases such as United States v. Carolene Products, the late New Deal Court indicated that economic legislation would enjoy a new presumption of legitimacy whether or not members of the Court approved of it. ${ }^{108}$ While most of these cases involved state legislation, the rational basis baseline also provided ample room for Congress to act.

In Carolene Products, the late New Deal Court applied rational basis review to a federal law barring the sale of "filled" milk" 109 and deferred to congressional fact-finding supporting the statute. ${ }^{10}$ In his famous footnote four, Justice Stone suggested that the Court would apply a higher level of scrutiny to legislation that infringed on fundamental rights, restricted the

guessing the acts of a coordinate branch. See supra notes 31-38 and accompanying text. Second, the Court's invalidation of state statutes is constitutionally mandated by both the Supremacy Clause and Section One of the Fourteenth Amendment. The Court's early history reflects its understanding of this point. The Court only invalidated two federal statutes between the years of 1790 and 1865 , but invalidated many state statutes. See Robert Lowry Clinton, MARBURY V. MADISON AND JUDICLAL REVIEW 20-30 (1989). After 1865, the Fourteenth Amendment amplified the power of the federal government vis-àvis the states, including the power of the federal courts to review the acts of state legislatures to ensure that they do not violate individual rights. Thanks to Leslie Goldstein for making this point to me.

106 William E. Forbath, LAW AND the Shaping of THE AMERICAN Labor MOVERMENT 39-40, 43-44 (1991).

107 ZIETLOW, ENFORCING EQUALITY, supra note 9, at 90-91.

108 See, e.g., United States v. Carolene Prod. Co., 304 U.S. 144 (1938).

$109 \mathrm{Id}$. at 152.

110 Id. ("[T]he existence of facts supporting the legislative judgment is to be presumed ...."). 
political process, or affected "discrete and insular minorities."111 Scholars have argued persuasively that the Warren Court's approach to judicial review was guided by footnote four's focus on improving the political process and protecting racial minorities. ${ }^{112}$ While some have questioned whether footnote four of Carolene Products actually influenced the Warren Court, ${ }^{113}$ the body of the opinion clearly provided a blueprint for that Court. In its opinions evaluating economic legislation, the Warren Court consistently applied a hands-off approach that reflected an underlying respect for the legislative process.

An early Warren Court case, Williamson v. Lee Optical, ${ }^{114}$ illustrates this point. In that case, the Court upheld the constitutionality of an Oklahoma statute that made it unlawful for a person not a licensed optometrist or opthamologist to fit lenses to a face or duplicate or replace lenses into frames except upon a written prescription. ${ }^{115}$ In an opinion written by Justice William $O$. Douglas, the Court agreed that the provision "may exact a needless, wasteful requirement in many cases."116 However, Douglas continued, "it is for the legislature, not the courts, to balance the advantages and disadvantages of the new requirement." 117 The Court concluded, "[f]or protection against abuses by legislatures the people must resort to the polls, not to the courts." 18 The Warren Court thus reaffirmed the deferential baseline for evaluating legislation from Carolene Products. Absent evidence of invidious discrimination, the Court would assume that the political process worked. ${ }^{119}$

In Ferguson v. Skrupa, The Warren Court appeared to be even more deferential to legislatures, rejecting a challenge to a Kansas statute that made it a misdemeanor for any person to engage "'in the business of debt

111 Id. at 153 n. 4 .

112 The most prominent example is ELY, supra note 44. See also PowE, supra note 7 , at 487 (describing this view as the "conventional view.").

113 See PowE, supra note 7, at 489 (challenging the view that the Warren Court was guided by Carolene Products and pointing out that the Warren Court rulings helped the same people who were benefiting from the political process at the time).

114348 U.S. 483 (1955).

$115 \mathrm{Id}$. at 485 . The statute exempted sellers of ready-to-wear glasses, prohibited radio and television advertisement of eyeglasses, prohibited soliciting the sale of framers or mountings, and prohibited firms and corporations engaged in real estate from renting space to persons conducting eye examinations. Id. at 485-89. The Court also rejected challenges to those provisions. Id.

116 Id. at 487.

117 Id.

118 Id. at 488 (citing Munn v. Illinois, 94 U.S. 113, 134 (1876)).

119 See id. at 489 ("The prohibition of the Equal Protection Clause goes no further than the invidious discrimination. We cannot say that that point has been reached here."). 
adjusting' except as an incident to 'the lawful practice of law in the state."'120 Skrupa, a debt adjuster who was not a lawyer, argued that the state could not prohibit him from practicing his profession because it was neither inherently immoral, nor dangerous, nor in any way contrary to the public welfare. ${ }^{121}$ The Court declined to comment on the merits of this argument, explaining:

Under the system of government created by our Constitution, it is up to legislatures, not courts, to decide on the wisdom and utility of legislation....

. . Unquestionably, there are arguments showing that the business of debt adjusting has social utility, but such arguments are properly addressed to the legislature, not to us. ${ }^{122}$

Once again, absent evidence of invidious discrimination, the Court deferred to the fact-finding capability of the legislature and assumed that the political process worked.

\section{B. Commerce Clause}

The legacy of the late New Deal Court is also reflected in the Warren Court's approach to the Commerce Clause, the principal source of congressional regulatory power. Just as it had in the area of substantive due process, the Court had applied heightened scrutiny to strike down early New Deal Commerce Clause-based measures such as the National Industrial Recovery Act. ${ }^{123}$ Indeed, it was President Roosevelt's frustration with those decisions that led him to attack the Court and recommend his Court-packing plan. ${ }^{124}$ Shortly thereafter, the Court adopted a deferential approach to uphold important measures such as the National Labor Relations Act, ${ }^{125}$ the Fair Labor Standards Act, ${ }^{126}$ and the Agricultural Adjustment Act. ${ }^{127}$ The

${ }^{120}$ Ferguson v. Skrupa, 372 U.S. 726, 726-27 (1963).

121 Id. at 727 .

122 Id. at $729,731$.

123 See A.L.A. Schechter Poultry Corp. v. United States, 295 U.S. 495, 550 (1935).

124 See KeVIn J. McMaHon, ReCONSIDERING Roosevelt on RaCE: How THE PRESIDENCY PAVED THE ROAD TO BROWN 48 (2003).

125 NLRB v. Jones \& Laughlin Steel Corp., 301 U.S. 1, 46-47 (1937).

126 United States v. Darby, 312 U.S. 100, 125 (1941).

127 Wickard v. Filburn, 317 U.S. 111, 128-29 (1942). See KECK, supra note 7, at 24 ("The Court abandoned its enforcement of long-standing constitutional limits on 
Warren Court relied on those precedents to uphold the 1964 Civil Rights Act in a decision which deferred to Congress's authority to address private discrimination. Thus, since 1964, Commerce Clause-based legislation has played a crucial role in shaping our nation's civil rights agenda. ${ }^{28}$

The 1964 Civil Rights Act was a landmark measure that outlawed race discrimination in places of public accommodation, employment, and education. ${ }^{129}$ The measure was based in Congress's power to enforce the Fourteenth Amendment and the Commerce Clause. In Heart of Atlanta Motel v. United States, the Court upheld Title II of the Act, the public accommodations provision, based on Congress's power to regulate interstate commerce. ${ }^{130}$ Justice Clark applied a relaxed form of rational basis review to the Commerce Clause, calling the commerce power "a specific and plenary one"131 that Congress could use as long as "the activity sought to be regulated is "commerce which concerns more states than one."132 Noting the "voluminous testimony" about the impact of race discrimination on the travel and other economic activity of African Americans, ${ }^{133}$ the Court held that the Act was a valid use of the commerce power even though it was aimed primarily at "moral wrongs." 134 Thus, the Court deferred to Congress's choice of means as well as its choice of ends. ${ }^{135}$

In the companion case, Katzenbach v. McClung, the Court upheld the application of the Act to a restaurant located in Birmingham, Alabama. ${ }^{136}$ Although the restaurant's connection to interstate commerce was considerably more attenuated than that of the motel, the Court found that the

legislative power, limits rooted in fundamental principles of limited government and private property rights. In place of these limits, many New Deal constitutionalists offered the Holmesian doctrine of majoritarian democracy and judicial self-restraint."); PowE, supra note 7 , at 4 .

128 See Post \& Siegel, Equal Protection, supra note 8, at 443.

129 The 1964 Act was extremely popular, with over seventy percent of Americans supporting it at the time of its passage, and its supporter, President Lyndon Johnson, was re-elected by a landslide shortly before the Court issued its opinions upholding the Act. See POWE, supra note 7, at 238.

130379 U.S. 241, 250 (1964).

131 Id. at 258.

132 Id. at 255 (quoting Gibbons v. Ogden, 22 U.S. (9 Wheat) 1, (1824)).

133 Id. at 253.

134 Id. at 257. While agreeing that the Act was a valid use of the commerce power, in concurrence, Justices Douglas and Goldberg argued that it also could be upheld as an exercise of Congress's Section Five power. Id. at 280 (Douglas, J., concurring), 293 (Goldberg, J., concurring).

135 The Court also rejected the motel's argument that the statute deprived it of liberty or property under the Fifth Amendment. Id. at 258-62.

136379 U.S. 294,305 (1964). 
restaurant's purchases of food that had moved in interstate commerce, and the aggregate effect of African-Americans reducing their spending due to racial discrimination like that practiced by the restaurant was a sufficient nexus to interstate commerce to rationally justify Congress's power to regulate. ${ }^{137}$ The Court noted, "where we find that the legislators, in light of the facts and testimony before them, have a rational basis for finding a chosen regulatory scheme necessary to the protection of commerce, our investigation is at an end." 138 Characterizing Congress's commerce power as "broad and sweeping," the Court all but abdicated its role in scrutinizing the commerce power. "[W] here [Congress] keeps within its sphere and violates no express constitutional limitation it has been the rule of this Court, going back almost to the founding days of the Republic, not to interfere."139

\section{Section Five}

Given the Warren Court's positive disposition towards rights of belonging and the civil rights movement, perhaps it is not surprising that the Court displayed the most deference toward Congress when evaluating civil rights measures enacted pursuant to the enforcement provisions of the Reconstruction Amendments. Section Five of the Fourteenth Amendment grants Congress the power to enforce its provisions by "appropriate legislation."140 Recognizing that members of the Reconstruction Congress saw themselves, and not the Court, as the primary enforcers of rights of belonging, the Warren Court interpreted these enforcement powers broadly. ${ }^{141}$ As in its other opinions evaluating congressional power, the Court applied rational basis to Section Five-based legislation. ${ }^{142}$ Moreover, passages of its opinions on Section Five power indicate deference not only

137 Id. at $298-99$.

138 Id. at 303-04.

$139 \mathrm{Id}$. at 305 . Five years later, in one of the last Warren Court opinions, a divided Court went even further and upheld application of the Act to a recreation club located in the mountains near Little Rock, Arkansas, accessible only by country roads. See Daniel v. Paul, 395 U.S. 298 (1969).

140 U.S. CONST. amend. XIV, § 5. The Fifteenth Amendment, which prohibits the denial of the franchise on account of race, contains a virtually identical enforcement clause, U.S. CONST. amend. XV, $\S 2$, and the Court treats the two clauses interchangeably.

141 See Katzenbach v. Morgan, 384 U.S. 641, 648 n.7 (1966); South Carolina v. Katzenbach, 383 U.S. 301, 326 (1966).

142 Robert C. Post \& Reva B. Siegel, Protecting the Constitution From the People: Juricentric Restrictions on Section Five Power, 78 IND. L.J. 1, 36 [hereinafter Protecting] ("Katzenbach applied to Section 5 power the same standards of deference that the postNew Deal Court has applied to every other grant of congressional authority."). 
to congressional remedial power, but arguably also to congressional autonomy to interpret the substance of the Constitution. ${ }^{143}$

In South Carolina v. Katzenbach, the Court upheld the constitutionality of the Voting Rights Act of 1965.144 Like the 1964 Civil Rights Act, the 1965 Voting Rights Act was a response to massive civil rights demonstrations protesting the denial of the franchise in the South, and was intended to enable the belonging of racial minorities to the national polity. ${ }^{145}$ The main focus of the Act was to outlaw literacy tests, which had been used in a racially discriminatory manner throughout the South. The Act created a complex scheme of remedies aimed at districts where voting discrimination was most likely to have occurred. For example, it prohibited the use of literacy tests in districts where the Attorney General determines that fewer than fifty percent of its residents are registered to vote, and authorized the appointment of federal electoral examiners in those districts. ${ }^{146}$ The blanket prohibition of literacy tests was arguably inconsistent with the Court's earlier ruling in Lassiter v. Northampton County Board of Elections, that literacy tests are not per se unconstitutional, because the statute did not require a finding of intentional discrimination before the tests would be outlawed. ${ }^{147}$ South Carolina argued that to allow Congress to enact such a bill would rob the courts of their rightful constitutional role, but the Court disagreed.

In the majority opinion, Chief Justice Earl Warren noted that the Framers had intended Congress to be "chiefly responsible for implementing the rights created in $\S 1 . " 148$ Thus, he concluded, "in addition to the courts, Congress has full remedial powers to effectuate the constitutional prohibition against racial discrimination in voting."149 The only question was whether the legislation was a rational means to effectuate this constitutional prohibition. ${ }^{150}$ Warren cited McCulloch v. Maryland to explain the Court's use of rational basis, noting that $\mathrm{McC}$ Culloch's broad

143 Id. at 34 ("Evidently the Warren Court saw nothing contradictory in simultaneously upholding the rule of law and deferring to Congress's Section 5 authority.").

144 South Carolina v. Katzenbach, 383 U.S. 301 (1966).

145 President Johnson introduced the Voting Rights Act only a week after the violence of the voting rights march in Selma, Alabama was televised nationally, and a Gallup Poll showed that fifty percent of Americans felt that the most important issue in the country was civil rights. PowE, supra note 7, at 257.

146 Voting Rights Act of 1965, Pub. L. No. 89-110, § 4(b), 79 Stat. 437 (codified at 42 U.S.C. $\S \S 1973 \mathrm{a}-\mathrm{p}(2000))$.

147360 U.S. 45 (1959).

148 South Carolina v. Katzenbach, 383 U.S. at 326.

149 Id.

${ }^{150} I d$. at 324 . 
vision of congressional power was "the basic test ... in all cases concerning the express powers of Congress with relation to the reserved powers of the states." 151 Applying rational basis, the Court had no trouble upholding $\S 4$ (b) of the 1965 Voting Rights Act. Even in Lassiter, the Court had deemed that literacy tests used with a discriminatory purpose would violate the Fifteenth Amendment. ${ }^{152}$ Hence, the Court deferred to Congress's findings that literacy tests had in all likelihood been used with a discriminatory purpose in the states most affected by the statute. ${ }^{153}$ This was a relatively easy case. ${ }^{154}$

Katzenbach $v$. Morgan was a considerably more difficult case. ${ }^{155}$ In Morgan, the Court evaluated the constitutionality of $\S 4(\mathrm{e})$ of the Voting Rights Act, which provided that no person who has successfully completed the sixth grade in a public school accredited by the Commonwealth of Puerto Rico in which the language of instruction was other than English could be denied the right to vote on account of his or her failure to read English. ${ }^{156}$ No court had ever held that New York State officials had used the literacy tests to discriminate on the basis of race, yet Congress relied on its Section Five power to enact this provision. Hence, the case raised the issue that the Court had skirted in the South Carolina case-to what extent did Congress have the autonomous authority to identify constitutional violations?

In his majority opinion, Justice William Brennan answered this question. He allowed Congress a great deal of autonomy to identify constitutional violations because "[a] construction of $\S 5$ that would require a judicial determination that the enforcement of the state law precluded by Congress violated the Amendment, as a condition of sustaining the congressional enactment, would depreciate both congressional resourcefulness and congressional responsibility for implementing the amendment."157 Noting

151 Id. at 326 ("Let the end be legitimate, let it be within the scope of the constitution, and all means which are appropriate, which are plainly adapted to that end, which are not prohibited, but consist with the letter and spirit of the constitution, are constitutional.") (citing McCulloch v. Maryland, 17 U.S. (4 Wheat.) 316, 421 (1819)).

152 Id. at 333-34 (citing Lassiter, 360 U.S. at 53).

153 Id.

154 Only Justice Black filed a partial dissent, objecting to the part of the opinion upholding the provisions of the Act that required certain states to ask for pre-clearance from the Attorney General before they could use qualifying devices like literacy tests. See id. at 355-62 (Black, J., concurring and dissenting).

155384 U.S. 641 (1966).

156 Voting Rights Act of 1965, 42 U.S.C. $\$ 1973$ b(e) (2003). The provision was sponsored by New York Senators Jacob Javits and Robert Kennedy, and it was intended to supercede a New York state law which required the ability to read and write in English as a condition of voting. Katzenbach, 384 U.S. at 645 n.3.

157 Katzenbach, 384 U.S. at 648. 
that Section Five was intended to give Congress "the same broad powers expressed in the Necessary and Proper Clause," the Court again cited McCulloch. ${ }^{158}$ The Court held that "Section 4(e) may be readily seen as "plainly adapted" to enforcing the Equal Protection Clause both as a measure to secure non-discriminatory treatment by the government and as a measure to enhance the political power of the Puerto Rican community to obtain better government services. ${ }^{159}$

The Court deferred to the fact-finding capabilities of Congress in weighing the extent of the Puerto Rican community's need for the measure. "It is not for us to review the congressional resolution of these factors. It is enough that we be able to perceive a basis upon which the Congress might resolve the conflict as it did." 160 The Court also deferred to Congress's assessment of the relationship between literacy in English and the ability to cast an informed vote. Citing Congress's "specially informed legislative competence," Brennan noted that "it was Congress's prerogative to weigh these competing considerations" and overrule the state's determination that literacy in English was necessary. ${ }^{161}$ Here, the Court applied the same deferential rational basis review to Section Five as it had to the commerce power in Heart of Atlanta Motel. The Court's approach in Morgan was even farther reaching, because the Court appeared to defer to congressional judgment about the meaning of the Constitution. ${ }^{162}$

The Morgan case was a landmark decision, and arguably an invitation for Congress to interpret the Fourteenth Amendment as broadly, and protectively, as members of Congress saw fit, regardless of the Court's interpretation of Section One. Former Solicitor General Archibold Cox certainly understood the decisions in that way. Writing in early 1966, Cox declared, "If the Congress follows the lead that the Court has provided, the last Term's opinions interpreting section 5 will prove as important in bespeaking national legislative authority to promote human rights as the Labor Board decisions of 1937 were in providing national authority to regulate the economy."163 Citing contemporary political theory that

${ }^{158} \mathrm{Id}$. at $650-51$.

$159 \mathrm{Id}$. at $652-53$.

160 Id. at 653 .

161 Id. at 656.

162 Justice Brennan left unanswered the extent to which the Court was ceding the authority to define constitutional rights to Congress, or simply the authority to anticipate violations of constitutional rights as identified by the Court. See Protecting, supra note 142 , at $35 \mathrm{n} .153$. Under the deferential watch of the Warren Court, however, the distinction was trivial. I owe this thought to Mark Graber.

163 Archibold Cox, The Supreme Court 1965 Term Foreword: Constitutional Adjudication and the Promotion of Human Rights, 80 HARV. L. REV. 91, 91 (1966) (footnote omitted). 
recognized the existence of positive rights, such as the right to jobs, medical care, social security and housing, Cox noted, "once government is held to have affirmative obligations to promote human rights much of the responsibility must shift to the legislative and executive branches." $164 \mathrm{He}$ believed that the Morgan decision would allow Congress to do just that. Most importantly, opined Cox, Congress might be able to use its Section Five power to remedy private discrimination, notwithstanding the Court's doctrine restricting the scope of Section One to state action. ${ }^{165}$

Six members of the Court said as much that same year in their concurrences to the Court's opinion in United States v. Guest. ${ }^{166}$ In Guest, several private individuals were indicted for depriving African Americans of the use of state-supported services, in violation of 18 U.S.C. $\$ 241$, a civil rights statute that dated back to the 1866 Civil Rights Act. ${ }^{167}$ A plurality of the Court held that $\S 241$ only applied to state action but that the facts supported a finding of state action. ${ }^{168}$ In two concurrences, six of the Justices agreed that Congress could use Section Five to address private action even though the scope of Section One was limited to state action. ${ }^{169}$

Speaking for a concurrence of three Justices that held that $\S 241$ did reach private discrimination but as such was constitutional, Justice Brennan rejected the argument that Congress's Section Five power was limited by the Court's earlier holding that Section One only applied to state action, ${ }^{170}$ protesting that such a view "reduces the legislative power to enforce the provisions of the Amendment to that of the judiciary." $171 \mathrm{He}$ explained, "Viewed in its proper perspective, $\S 5$ of the Fourteenth Amendment appears as a positive grant of legislative power, authorizing Congress to exercise its discretion in fashioning remedies to achieve civil and political equality for all citizens." 172 In a short concurrence with little explanation, Justices Clark, Black, and Fortas agreed with the plurality that $\S 241$ did not address state action, but added without explanation, "there now can be no doubt that the specific language of $\S 5$ empowers the Congress to enact laws punishing all conspiracies-with or without state action-that interfere with Fourteenth

164 Id. at 94.

165 Cox argued that Congress could use its Section Five power to address private discrimination "where that is a means of implementing the prohibition against the state." Id. at 102.

166383 U.S. 745 (1966). See Cox, supra note 163, at 108.

167 Guest, 383 U.S. at 747.

168 Id. at 754.

${ }^{169} \mathrm{Id}$. at 783 (Brennan, J., concurring); id. at 762 (Clark, J., concurring).

170 See Civil Rights Cases, 109 U.S. 3, 13 (1883).

171 Guest, 383 U.S. at 783. (Brennan, J., concurring).

172 Id. at 784 (Brennan, J., concurring). 
Amendment rights." 173 These opinions supported Cox's argument that Congress could use Section Five to do away with the state action requirement regardless of how the Court interpreted Section One, suggesting that Congress had wide autonomy to address private discrimination. ${ }^{174}$

\section{Thirteenth Amendment}

The Warren Court also took a deferential approach to congressional power to enforce another Reconstruction Amendment, the Thirteenth Amendment, which prohibits slavery and involuntary servitude. Section Two of that Amendment is virtually identical to the enforcement provisions of the other Reconstruction Amendments. ${ }^{175}$ Unlike the Fourteenth and Fifteenth Amendments, however, on its face the Thirteenth Amendment clearly applies to private action. ${ }^{176}$ In the case of Jones $v$. Mayer, plaintiffs alleged that defendant had refused to sell them a home because they were African Americans, in violation of a provision of the 1866 Civil Rights Act that prohibited race discrimination in the sale of real estate. ${ }^{177}$ In the majority opinion, Justice Potter Stewart held that the Thirteenth Amendment enforcement power authorized Congress to legislate to abolish "all badges and incidents of slavery," and applied rational basis review to the use of that power. ${ }^{178}$

The Court held that Congress's determination that race discrimination in real estate transactions was a badge or incident of slavery was a rational one. Many of the Black Codes had limited the rights of blacks to buy property. "And when racial discrimination herds men into ghettos and makes their ability to buy property turn on the color of their skin, then it too is a relic of slavery." 179 The Court's decision in Jones has enormous symbolic

173 Id. at 762 (Clark, J., concurring). The plurality opinion held that $\S 241$ required state action, but that the state action requirement was satisfied.

174 See Cox, supra note 163, at 115. See also Post \& Siegel, Equal Protection, supra note 8 , at 501 (arguing that in Guest, " $[\mathrm{t}]$ hrough a combination of interpretive strategems, the Court decisively freed federal antidiscrimination legislation from the state action requirement it preserved for its own Section 1 cases").

175 See U.S. CONST. amend. XIII, $\S 2$ ("Congress shall have power to enforce this article by appropriate legislation.").

176 See U.S. CONST. amend. XIII, $\S 1$ ("Neither slavery nor involuntary servitude . . . shall exist within the United States ....").

177 Jones v. Alfred Mayer Co., 392 U.S. 409, 412-13 (1968); see also 42 U.S.C. $\S 1982(2000)$.

178 Jones, 392 U.S. at $439-40$ ("Surely Congress has the power under the Thirteenth Amendment rationally to determine what are the badges and the incidents of slavery, and the authority to translate that determination into effective legislation.").

${ }^{179}$ Id. at $442-43$. 
significance. ${ }^{180}$ Its ruling gave $\S 1982$ the broadest possible interpretation and in effect overturned the limited interpretation of Thirteenth Amendment enforcement power in the Civil Rights Cases. ${ }^{181}$ Moreover, by reinvigorating this Reconstruction Era statute, the Court summoned the spirit of the Reconstruction Congress, yet rejected the activist intrusion of the Court of that era. Once again, the Warren Court deferred to Congress and championed Congress's role as a protector of rights of belonging.

\section{E. Congress in the Second Reconstruction}

The Warren Court's restraint towards congressional power to protect rights of belonging reinforced ongoing congressional activism to protect those rights. After the Court upheld the 1964 Civil Rights Act, "a political logic took hold in which the elected branches of government perceived distinct rewards for approving civil rights legislation." 182 The judicial restraint of the Warren Court enabled Congress to play a leading role in this transformation by protecting rights of belonging in our society. Starting in the New Deal, federal statutes had been essential for the establishment of workers' rights and an economic safety net. ${ }^{183}$ Beginning in 1964, statutes also became central to the nation's civil rights agenda. ${ }^{184}$

The 1964 Civil Rights Act and the 1965 Voting Rights Act were just the beginning of a period of congressional activism in protecting rights of belonging. By the mid-1970s, Congress had adopted the most far-reaching measures to protect those rights in our history. Other federal legislation prohibiting discrimination on the basis of race includes the Fair Housing Act, which prohibits race discrimination in real estate transactions, ${ }^{185}$ and

180 As Robert Post and Reva Siegel have observed, the Court's broad interpretation of the Thirteenth Amendment enforcement clause in Jones "essentially ceded to Congress sufficient constitutional authority to regulate the full range of discriminatory conduct by private actors it sought to reach." Post \& Siegel, Equal Protection, supra note 8, at 496.

181 See Civil Rights Cases, 109 U.S. 3, 22-23 (1883).

182 Stephen M. Griffin, Judicial Supremacy and Equal Protection in a Democracy of Rights, 4 U. PA. J. CONST. L. 281, 291 (2002).

183 See ZIETLOW, ENFORCING EQUALITY, supra note 9, at 72-75.

${ }^{184} \mathrm{Id}$. at ch. 5. See also William N. Eskridge, Reneging on History? Playing the Court/Congress/President Civil Rights Game, 79 CAL. L. REv. 613, 615 (1991).

185 Fair Housing Act, Pub. L. No. 90-284, Title VIII, $\S 817,82$ Stat. 89 (1968) (codified at 42 U.S.C. $\S \S 3601-3619$ (2000)) (providing federal grants to state or local governments for the purpose of preventing or eliminating discriminatory housing practices). 
the Equal Credit Opportunity Act of 1974. ${ }^{186}$ Congress enacted legislation prohibiting gender discrimination well before the Court recognized gender as a protected class, ${ }^{187}$ including the Equal Pay Act of 1963, Title VII of the 1964 Civil Rights Act, Title IX of the Education Amendments of 1972, and the Pregnancy Discrimination Act of $1978 .{ }^{188}$ During this period, Congress also expanded the classifications of people whose rights were entitled to protection beyond those classifications recognized by the Court, prohibiting discrimination against the disabled ${ }^{189}$ and the elderly 190 and mandating access to public education for disabled children. ${ }^{191}$ Finally, Congress expanded the economic safety net that it had established during the New

186 Equal Credit Opportunity Act of 1974, Pub. L. No. 93-495, Title V, 88 Stat. 1521 (codified at 15 U.S.C. $\$ \S 1691 \mathrm{a}-1691 \mathrm{f}(2000)$ ) (prohibiting discrimination on the basis of race, religion, sex, and age in lending).

187 See Frontiero v. Richardson, 411 U.S. 677 (1973); Post \& Siegel, supra note 3, at $1995 \mathrm{n} .158$ (2003); Reva B. Siegel, Text in Contest: Gender and the Constitution From a Social Movement Perspective, 150 U. PA. L. REV. 297 (2001).

188 Education Amendments of 1972, Tit. IX, 20 U.S.C. $\$ 1681$ (2000) (prohibiting discrimination on the basis of sex in programs or activities receiving federal financial assistance). See also The Women in Apprenticeship and Non-Traditional Occupations Act, Pub. L. No. 102-530, 106 Stat. 3465 (1992) (codified at 29 U.S.C. $\S \S 2501-2509$ (2000)) (providing grants to community-based organizations that deliver technical assistance to the preparation of employers to recruit, train, and employ women).

189 The Rehabilitation Act of 1973, 29 U.S.C. $\$ \S 701-96$ (2003) (prohibiting discrimination against the disabled by recipients of federal funds); The Americans with Disabilities Act of 1990, Pub. L. No. 101-336, 104 Stat. 330 (codified at 42 U.S.C. $\$ \S 12101-12213$ (2000)) (prohibiting discrimination on the basis of disability by state and private employers and requiring state facilities to be accessible to the disabled). But cf. City of Cleburne v. Cleburne Living Center, 473 U.S. 432 (1985) (rejecting plaintiffs' claim that the disabled were entitled to heightened protection).

190 The Age Discrimination Act of 1975, 42 U.S.C. $\$ \S 6101-6107$ (2000 \& Supp. IV 2004) (prohibiting discrimination on the basis of age in programs or activities receiving federal financial assistance). But cf. Mass. Bd. of Retirement v. Murgia, 427 U.S. 307, 313-14 (1976) (rejecting plaintiffs' claim that classifications based on age should be subjected to heightened scrutiny).

191 Elementary and Secondary Education Act; Education for All Handicapped Children Act of 1975 (now the Individuals with Disabilities Education Act), 20 U.S.C. $\S \S 1400-1409$ (2000 \& Supp. IV 2004) (requiring states to provide adequate educational facilities to disabled children in order to insure all disabled children the availability of a free, appropriate education). But cf. San Antonio Independent School Dist. v. Rodriguez, 411 U.S. 1, 36-37 (1973) (finding no fundamental right to education). 
Deal and enacted other anti-poverty measures, including Medicaid, ${ }^{192}$ Medicare, ${ }^{193}$ and the Supplemental Security Income program. ${ }^{194}$

Even as the Rehnquist Court began its cutbacks on congressional power, Congress continued in its enduring role of protecting rights of belonging with statutes including the Americans with Disabilities Act of $1990,{ }^{195}$ the Civil Rights Act of $1991,{ }^{196}$ the Family and Medical Leave Act of 1993, ${ }^{197}$ the civil rights provision of the Violence Against Women Act of 1994, 198 and the Church Arson Prevention Act in 1996. ${ }^{199}$ All of these statutes greatly expanded the rights of belonging of people in our country. The judicial restraint of the Warren Court helped to make them possible.

\section{THE ACTIVISM OF THE REHNQUIST COURT}

Unfortunately, the Rehnquist Court did not share the Warren Court's deference for its coordinate legislative branch. Instead, it adopted the activist approach towards Congress reminiscent of the Warren Court's predecessors. Permeating many of the Rehnquist Court's decisions is a deep distrust of

192 Medicaid Act, Pub. L. No. 89-97, Title XVIII, § 121(a), 79 Stat. 343 (codified at 42 U.S.C. $\S \S 1396-1396 v$ (2000 \& Supp. IV 2004)).

193 Health Insurance for the Aged Act, Pub. L. No, 89-97, Title I, 79 Stat. 290 (codified at 42 U.S.C. $\$ \S 401-434$ (2000 \& Supp. IV 2004)).

194 Social Services Amendments of 1974, Pub. L. No. 93-647, 88 Stat. 2337 (codified at 42 U.S.C. $\S \S 651-669 b$ (2000 \& Supp. IV 2004)). In addition, in the Economic Opportunity Act of 1964, Congress created ten federal programs to fight poverty, including the Office of Economic Opportunity, Head Start, and community action programs. See Nicholas LEMANN, THE PROMISED LAND: THE GREAT BLACK Migration AND How IT CHANGED AMERICA 156-58 (1992). Some civil rights leaders, including Martin Luther King, saw economic justice as essential to achieving civil rights. See Forbath, supra note 61, at 85-88 (1999) (discussing a campaign by some civil rights leaders for economic rights as well as "civil" rights). The Court rejected claims of constitutional protection based on poverty. See Dandridge v. Williams, 397 U.S. 471, 485-87 (1970).

195 Pub. L. No. 101-336, 104 Stat. 330 (codified at 42 U.S.C. $\S \S 12101-12213$ (2000)).

196 Civil Rights Act of 1991, Pub. L. No. 102-166, 105 Stat 1071 (codified at 42 U.S.C. $\S \S 1981-2000 \mathrm{~h}$ (2003)). See also Serena J. Hoy, Interpreting Equal Protection: Congress, the Court, and the Civil Rights Acts, 16 J.L. \& PoL. 381, 439 (2000).

197 Family and Medical Leave Act of 1993, Pub. L. No. 103-3, 107 Stat. 6 (codified at 29 U.S.C. $\S \S 2601-2654$ (2000)).

198 Civil Right Remedies for Gender Motivated Violence, Pub. L. No. 103-322, 108 Stat. 1941 (codified at 42 U.S.C. $\$ 13981$ (c) (2000)).

199 Church Arson Prevention Act of 1996, Pub. L. 104-155, 110 Stat. 1392 (codified at 18 U.S.C. $\S 241(2000)$ ). 
politicians and the legislative process. ${ }^{200}$ While the Court's intervention in the political process in its Bush v. Gore ${ }^{201}$ decision may be the most wellknown example of this phenomenon, ${ }^{202}$ the most problematic manifestation of that activism was the Court's cutbacks on congressional power to protect rights of belonging. ${ }^{203}$ The Rehnquist Court replaced the Warren Court's activism with a harsher, more conservative activism, "protecting state governments from civil rights plaintiffs, state officers from federal regulatory mandates, property owners from environmental regulation, and whites from affirmative action." 204 In a series of decisions, the Rehnquist Court imposed heightened scrutiny on federal legislation protecting rights of belonging and rejected congressional findings of law and fact supporting that legislation. ${ }^{205}$ These rulings inhibited the "democratic vindication of equality values,"206 placing our rights of belonging in jeopardy. 207

\section{A. Commerce Clause}

In United States v. Lopez ${ }^{208}$ and United States v. Morrison, ${ }^{209}$ the Rehnquist Court restricted Congress's Commerce Clause powers-and, correspondingly, limited its ability to define rights of belonging. Most notably, in Morrison, the Court struck down the civil rights provision of the Violence Against Women Act as beyond the Commerce Clause power. ${ }^{210}$ Congress had labeled the measure a civil rights act and compiled an extensive factual record documenting the overwhelming impact of gender-

200 See Balkin \& Levinson, supra note 7, at 1062 ("Perhaps the only theme that Bush v. Gore shares with the other cases we have discussed is the conservative majority's apparent distrust of the Congress and of the national political process.").

201531 U.S. 98 (2000).

202 Balkin \& Levinson, supra note 7, at 1084 (arguing that in Bush v. Gore, "[t]he five Justice majority used the power of judicial review to short circuit the process of democratic representation, install a president of their choice, and help keep their revolution going").

203 See Colker \& Brudney, supra note 17, at 83; Post \& Siegel, Equal Protection, supra note 8, at 522; Rubenfeld, supra note 21 , at 1144.

204 Balkin \& Levinson, supra note 7, at 1092. The developments have inspired Thomas Keck to label the Rehnquist Court "the most activist in American history." See KECK, supra note 7, at 285.

205 See, e.g., Bd. of Trs. of Univ. of Ala. v. Garrett, 531 U.S. 356 (2001); United States v. Morrison, 529 U.S. 598 (2000); Kimel v. Fla. Bd. of Regents, 528 U.S. 62 (2000).

206 Post \& Siegel, Equal Protection, supra note 8, at 522.

207 See Morgan \& Zietlow, supra note 9, at 1350-66. For an excellent compilation of works describing the impact of Rehnquist Court rulings on our individual rights, see AWAKENING FROM THE DREAM: CIVIL RIGHTS UNDER SIEGE AND THE NEW STRUGGLE FOR EQuAl JustiCE (Denise C. Morgan, Rachel D. Godsil, \& Joy Moses eds., 2005). 
motivated violence on interstate commerce. ${ }^{211}$ Ignoring Congress's designation of the law as a civil rights measure, the Court framed the statute as a "family law" measure and held that it was beyond the Commerce Clause because it regulated activity that was not economic. ${ }^{212}$ Even more striking, the Court breezily disregarded Congress's factual record, noting merely "the existence of congressional findings is not sufficient, by itself, to sustain the constitutionality of Commerce Clause legislation."213

Congress had often used the Commerce Clause to enact antidiscrimination laws and protective labor laws, and the Morrison decision signaled an ominous return to early New Deal decisions where the Court imposed categorical limitations and struck down such laws. ${ }^{214}$ Although the Rehnquist Court rejected some challenges to Commerce Clause legislation in its last years, it retained the categorical distinction between what the Court defines as economic and non-economic legislation in those cases. ${ }^{215}$ Most importantly, the Court's casual disregard of Congress's fact finding in Morrison stands as a sharp contrast to the deferential rational basis approach of the Warren Court toward Congress's use of the Commerce Clause to protect rights of belonging.

\section{B. Section Five}

The Rehnquist Court's restrictions on Congress's power to enforce the Fourteenth Amendment pursuant to Section Five of that Amendment marked its most dramatic departure from the Warren Court's jurisprudence. In City of Boerne v. Flores, the Rehnquist Court struck down the Religious Freedom Restoration Act as beyond the scope of the Section Five power because Congress had gone beyond its proper, remedial role when it enacted the statute, and the Court established a new "congruence and proportionality"

208514 U.S. 549 (1995).

209529 U.S. 598 (2000).

${ }^{210}$ Id. at 627 .

211 Id. at 614 .

212 Id. at 613, 617. See Judith Resnik, Categorical Federalism: Jurisdiction, Gender, and the Globe, 111 YALE L.J. 619, 628 (2001).

${ }^{213}$ Morrison, 529 U.S. at 614.

214 See, e.g., Carter v. Carter Coal Co., 298 U.S. 238 (1936); A.L.A. Schechter Poultry Corp. v. United States, 295 U.S. 495 (1935); Post \& Siegel, Equal Protection, supra note 8, at 449.

${ }^{215}$ See Gonzales v. Raich, 545 U.S. 1, 22 (2005) (upholding the federal ban on private cultivation and use of marijuana); Pierce County v. Guillen, 537 U.S. 129, 147 (2003) (upholding a federal statute protecting reports and surveys compiled by state agencies from state discovery laws). 
test to evaluate the constitutionality of Section Five-based legislation. ${ }^{216}$ The Court rejected the argument that the Morgan precedent allowed Congress autonomy to determine the meaning of the Fourteenth Amendment and emphatically asserted its own preeminence in constitutional interpretation, maintaining that when Congress attempts to define the substance of unconstitutional conduct, it intrudes on the proper function of "the Judicial Branch ... to say what the law is." 217 Rather than acting as a partner with Congress in protecting rights of belonging, the Rehnquist Court viewed Congress as an opponent, threatening the Court's preeminence in matters of constitutional interpretation. ${ }^{218}$ Boerne thus severely curtails congressional autonomy to protect rights of belonging. 219

Rehnquist Court decisions applying Boerne treated the "congruence and proportionality" test as a type of strict scrutiny, carefully analyzing both the ends and means to strike down statutes protecting the rights of belonging of state employees. For example, in Kimel v. Florida Board of Regents ${ }^{220}$ and Board of Trustees of the University of Alabama v. Garrett, ${ }^{221}$ the Court applied that test and struck down provisions authorizing state employees to sue their employers for age discrimination and discrimination on the basis of disability, respectively. In both instances, the Court determined that Congress lacked Section Five authority because the statutes were not

216521 U.S. 507, 519-20 (1997). Like Smith, Boerne overruled existing precedent. Prior to Boerne, the Court had applied the deferential "rational basis" test to Congress's use of its Section Five power. See Katzenbach v. Morgan, 384 U.S. 641, 651 (1966).

217 Boerne, 521 U.S. at 536. The Court cited to Marbury v. Madison for the proposition that congressional interpretation of the Constitution would place the Constitution "on a level with ordinary legislative acts." Id. at 529 (quoting Marbury v. Madison, 5 U.S. (1 Cranch) 137, 177 (1803)).

218 Post \& Siegel, Equal Protection, supra note 8, at 454 ("What really seems to be at stake for the Court in the distinction between remedial and substantive legislation is the preservation of judicial control over the ultimate meaning of the Constitution.").

${ }^{219}$ See KECK, supra note 7, at 239 (Section Five cases are particularly notable since they "significantly narrow [ ] Congress's authority in the civil rights field.").

220528 U.S. 62 (2000). The Kimel Court held that the ADEA would make much more conduct illegal than had previously been held to be unconstitutional under the Equal Protection Clause, and, thus, would impermissibly heighten the standard of scrutiny beyond that established by the Court for age-based classifications. Id. at 86 .

221531 U.S. 356 (2001). The Garrett Court found that even if there was a pattern of unconstitutional discrimination by the states, Title I of the ADA failed the congruence and proportionality test because it forbids disparate impact discrimination, which is "insufficient [to state a cause of action] even where the Fourteenth Amendment subjects state action to strict scrutiny." Id. at 373 . 
appropriate remedial legislation under the congruence and proportionality test. ${ }^{222}$

Most notable was the Court's treatment in Garrett of the extensive factual record that Congress had compiled in support of its determination that people with disabilities were a "discrete and insular minority." 223 Congress had held numerous hearings throughout the United States at which people with disabilities had reported experiencing discrimination. Yet, just as it had in Morrison, the Court disregarded Congress's factual record, pointing out that most (though not all) of it related to employees of private companies, not state employees. ${ }^{224}$ In these cases, the Rehnquist Court exhibited a marked lack of deference to Congress's authority "at the expense of its own independent judgment about the correct legal outcome."225

\section{Sovereign Immunity}

Finally, the Rehnquist Court limited congressional authority to protect rights of belonging by reviving the doctrine of sovereign immunity to impose limitations on the ability of individual civil rights plaintiffs to sue states for violating their rights, and on Congress's authority to authorize individuals to bring such suits. The Court held that Congress cannot use its Article I powers to abrogate sovereign immunity, ${ }^{226}$ and narrowly interpreted the only source of power remaining to Congress-Section Five

222 See Kimel, 528 U.S. at 81-88; Garrett, 531 U.S. at 365-67. See also Fla. Prepaid Postsecondary Educ. Expense Bd. v. Coll. Sav. Bank, 527 U.S. 627, 639 (1999).

223 Americans with Disabilities Act of 1990, Pub. L. No. 101-336, § 12101(a)(7), 104 Stat. 329 (codified at 42 U.S.C. $\$ \S 12101-12213$ (2000)).

224 The Court was considerably more deferential to congressional fact-finding when evaluating the Family Medical Leave Act as a sex equality measure in Nevada v. Hibbs. See Nev. Dep't. of Human Res. v. Hibbs, 538 U.S. 721, 744-59 (2003) (Kennedy, J., dissenting). Justice Rehnquist's majority opinion noted that the Court's deference was due to the fact that the Court had recognized a history of states discriminating on the basis of gender. Id. at 729. This aspect of the opinion reinforces the Court's position that the Court, and not Congress, is qualified to recognize a constitutional violation. Id.

225 Young, supra note 27, at 1145. Indeed, even though the Supreme Court acknowledged Congress's power to enact the Family and Medical Leave Act pursuant to its Section Five powers in Hibbs, the Hibbs Court reiterated the congruence and proportionality test and reemphasized "that it falls to this Court, not Congress, to define the substance of constitutional guarantees." Hibbs, 538 U.S. at 728. See also Tennessee v. Lane, 341 U.S. 509, 520-21 (2004) (reiterating the congruence and proportionality test, but upholding the constitutionality of Title II of the ADA, which requires that public services and programs be accessible to the disabled, because laws affecting the right of access to courts have been strictly scrutinized by the Supreme Court).

226 See Alden v. Maine, 527 U.S. 706, 712 (1999); Seminole Tribe v. Florida, 517 U.S. 44, 72 (1996); Morgan \& Zietlow, supra note 9, at 1361-63. 
of the Fourteenth Amendment. ${ }^{227}$ The sovereign immunity cases are particularly significant because they deprive Congress of the only effective means of ensuring that rights of belonging are enforced against state governments. 228

\section{THE IMPORTANCE OF CONGRESSIONAL AUTONOMY}

In today's political climate, the debate over judicial activism is integrally entwined with the debate over the role of values in law. Politicians on the right of the political spectrum have achieved significant political success arguing that unaccountable judges should not determine the meaning of the word marriage or the extent of the "right to life." Those on the political left have found it difficult to answer these claims. Rather than engaging in debate over the scope and meaning of values, they call for moral neutrality in the political realm ${ }^{229}$ and defend judicial decisions that established those rights. This is a mistake. In large part due to the paradigm of the activist Warren Court, courts as protectors of rights have also played a hegemonic role in constitutional scholarship. Paradoxically, however, it is the judicial restraint of the Warren Court that provides the best model of the proper relationship of the governmental branches with regard to rights of belonging.

For too long, proponents of rights of belonging have depended on courts to uphold their values. ${ }^{230}$ This is problematic not because most courts are not as proactive at protecting those rights as was the Warren Court, but because courts are simply not well-suited to creating a robust model of rights of belonging. Constitutional scholars who support an expansion of rights of belonging should not fear the political debate over the meaning and scope of rights of belonging. Not only have legislatures been more protective of those rights throughout the history of our country, but they are better-suited institutionally than courts to defining and protecting those rights.

Rights of belonging serve to shape and define our community. The reason why the "moral values" message of the political right has been so successful is that people naturally yearn for shared values and a shared sense of community. 231 Those on the left should also be speaking about their values and emphasizing the importance of community-a community that is

227 See City of Boerne v. Flores, 521 U.S. 507, 518-20 (1997).

228 See Pamela S. Karlan, Disarming the Private Attorney General, 2003 U. ILL. L. REV. 183 (2003).

${ }^{229}$ See Michael J. SANDEL, Democracy's Discontent 7 (1996).

${ }^{230}$ See GLENDON, supra note 25, at 6.

231 See generally GEORGE LAKOFF, DON'T THINK OF AN ELEPHANT (2004). 
more inclusive and is based on a more expansive vision of who belongs to it. ${ }^{232}$ This must be done in the political arena, and cannot be confined to courts. Because courts are by and large external to that community, they are less well-suited to define it. ${ }^{233}$ Moreover, the litigation process, with its jurisdictional barriers and limited fact-finding capabilities, is simply not as effective a forum for debating fundamental values as is the open-ended political process. ${ }^{234}$ Congressional protection of rights of belonging also enjoys a number of institutional advantages over court protection of those rights, including accountability, transparency, enforceability, and flexibility in creating remedies. ${ }^{235}$ Most importantly, the political process entails an open debate in which diverse groups can participate, and furthers the agency of political actors, including grass roots activists. ${ }^{236}$ The act of engaging in the political debate is itself an act of belonging, and can be extremely empowering for those who have historically been excluded or marginalized. 237

The members of the Warren Court recognized the importance of political engagement and allowed a great deal of latitude for members of Congress to resolve the most pressing moral issues of their time-the scope and meaning of rights of belonging. Yet, for some reason, this wisdom has been lost and obscured in the conventional understanding of the Warren

232 See SANDEL, supra note 229, at 4.

233 See ZIETLOW, ENFORCING EQUALITY, supra note 9, at ch. 8 (discussing the connection between rights of belonging and community).

234 As Mark Tushnet has pointed out, there is also a danger that a loss in the courts will stymie the political debate. See TUSHNET, supra note 6, at 169-72. Due to a number of Rehnquist Court rulings, the jurisdictional barriers to "impact" litigation have also increased significantly in recent years. See Morgan \& Zietlow, supra note 9, at 1356-66.

235 For a comprehensive discussion of those advantages, see ZIETLOW, ENFORCING EQUALITY, supra note 9, at ch. 7 (comparing the institutional strengths and weaknesses of legislatures and courts as protectors of rights of belonging). See also William D. Araiza, Courts, Congress and Equal Protection: What Brown Teaches Us About the Section 5 Power, 47 How. L.J. 199, 226-27 (2004); Frank B. Cross, Institutions and Enforcement of the Bill of Rights, 85 CORNELL L. REV. 1529 (2000).

236 ZIETLOW, ENFORCING EQUALITY, supra note 9, at 164-68. It is important not to exaggerate these aspects of the congressional process. Many (perhaps most) important decisions in Congress are made behind closed doors, and compromises of principle are often made away from the watchful eyes of the people. However, the fact remains that "Congressional decisions still turn on whether appropriate [reasonable] justifications can be found for a vote." Kramer, supra note 2, at 1001.

${ }^{237}$ Moreover, the prevalence and accessibility of political blogs has significantly expanded the accessibility of this debate to those with fewer financial resources. 
Court Era by those on both sides of the political spectrum. ${ }^{238}$ Progressives have always understood the value of the activism of the Warren Court. The time has come to appreciate the value of that Court's restraint.

\section{CONCLUSION}

The view of the Warren Court as an activist protector of minority rights has become the conventional paradigm of the relationship between courts and legislatures with regard to rights of belonging. While the Warren Court's defense of rights of belonging was certainly admirable, that role was neither paradigmatic of how courts operate in our constitutional system, nor does it tell the whole story about that Court. Discrete and insular minorities must resort to courts when the political process fails them. Still, the Framers of the Fourteenth Amendment saw Congress as the primary protector of those rights, and based on that understanding, the Warren Court allowed Congress to play that role.

Appreciating the restraint of the Warren Court is necessary not only to set the record straight, but also to reinvigorate the enduring role that Congress has played in protecting rights of belonging throughout the history of our country. Once we understand that Congress, and not the Court, is both the most likely and the best-suited institution to protect those rights, then we can begin to engage in the political debate that is necessary for a robust model of rights of belonging in our society. The Warren Court recognized the value of this political debate-we should too.

${ }^{238}$ A notable exception to this pattern is PowE, supra note 7 , in which the author thoroughly analyzes the interaction between the Warren Court and the politics of the time. 


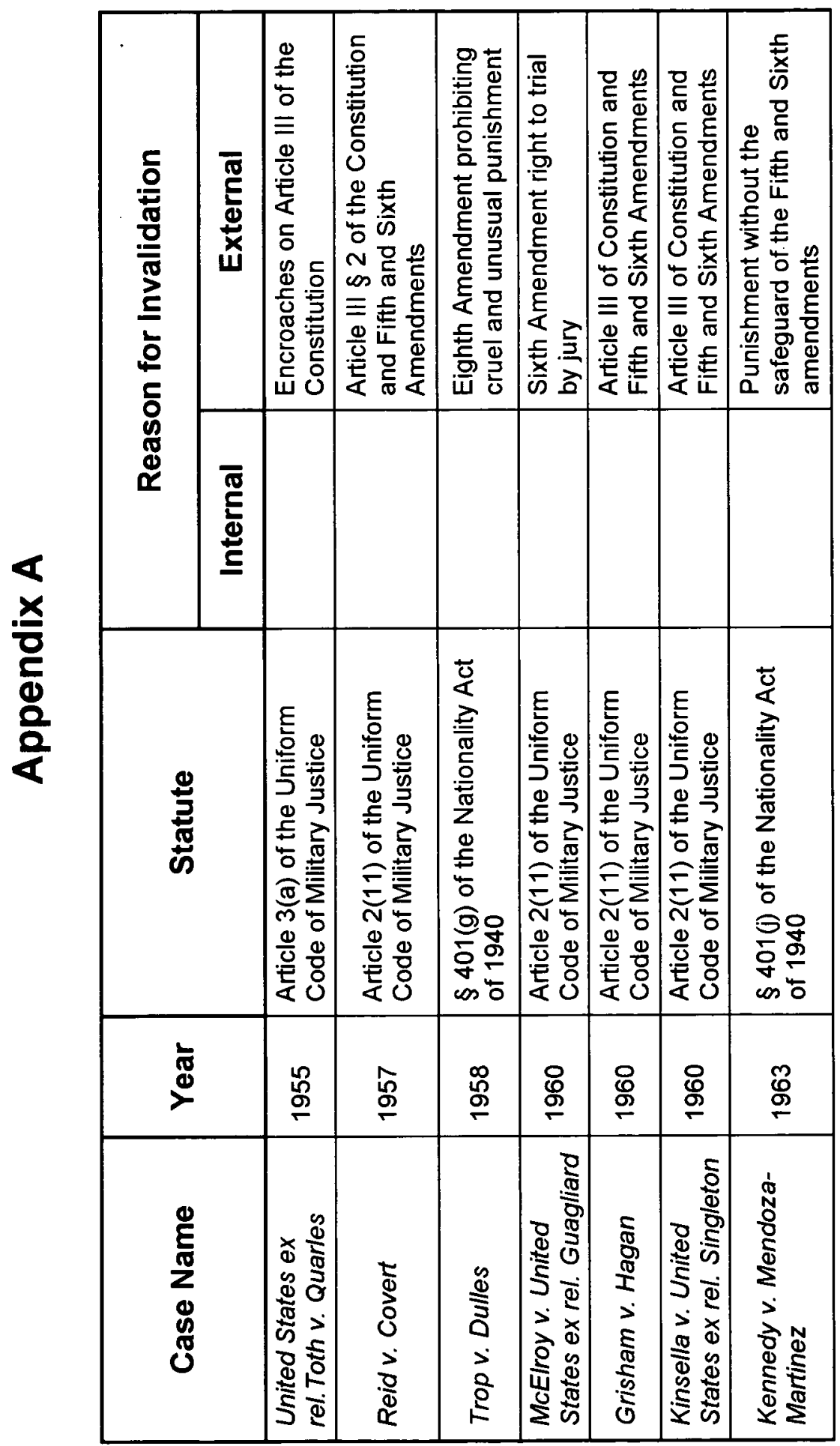




\begin{tabular}{|c|c|c|c|c|c|c|c|c|c|}
\hline \multirow{2}{*}{ 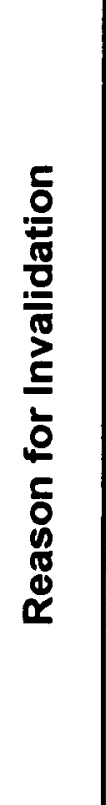 } & 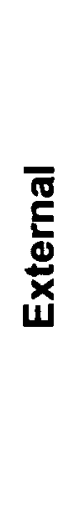 & 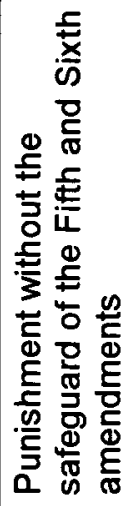 & 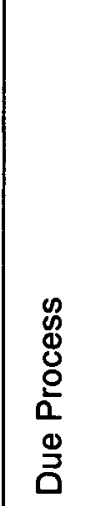 & 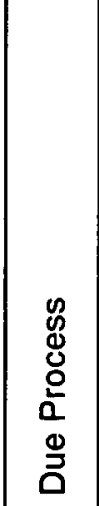 & 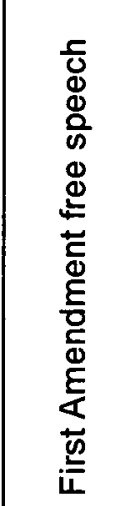 & 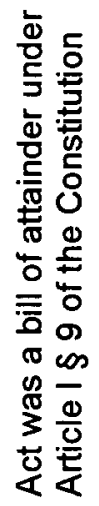 & 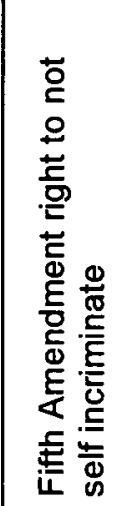 & 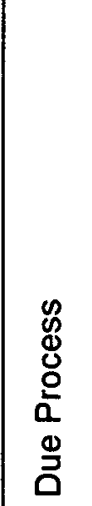 & 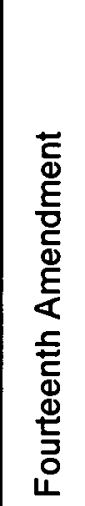 \\
\hline & 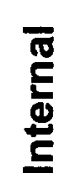 & & & & & & & & \\
\hline \multicolumn{2}{|c|}{$\underset{\frac{D}{3}}{\frac{\Phi}{3}}$} & 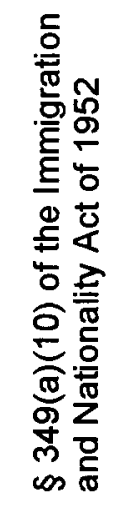 & 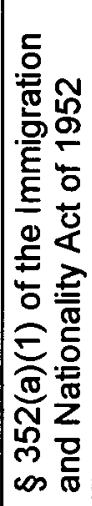 & 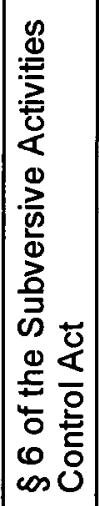 & 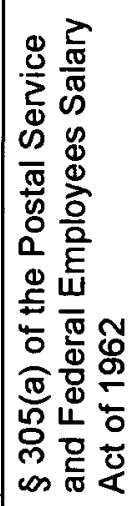 & 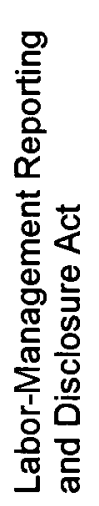 & 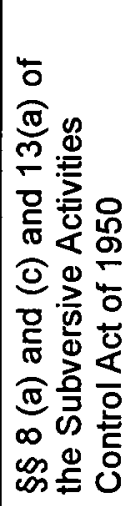 & 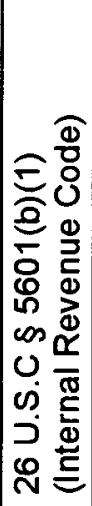 & 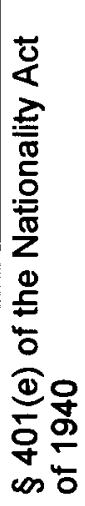 \\
\hline 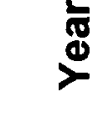 & & ஜֶ & 莺 & $\begin{array}{l}\text { ષั } \\
\stackrel{2}{\leftarrow}\end{array}$ & 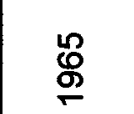 & 苋 & ஜ & $\begin{array}{l}\text { ஜீ } \\
\stackrel{8}{\circ}\end{array}$ & ڤ్ \\
\hline 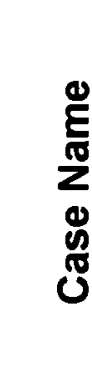 & & 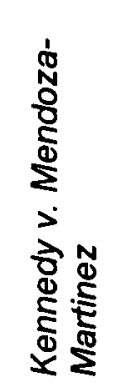 & 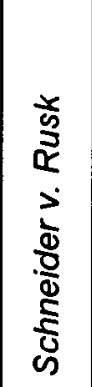 & 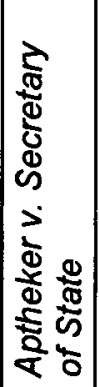 & 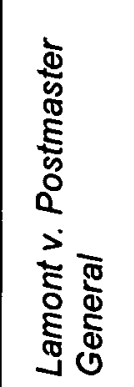 & $\begin{array}{l}5 \\
5 \\
0 \\
0 \\
0 \\
> \\
8 \\
0 \\
05 \\
5 \\
0 \\
0 \\
0 \\
: 5 \\
5\end{array}$ & 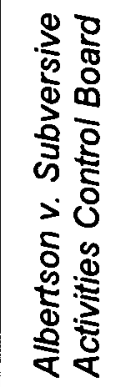 & 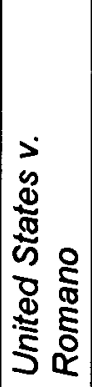 & 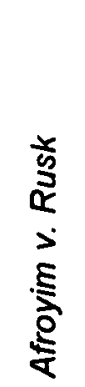 \\
\hline
\end{tabular}




\begin{tabular}{|c|c|c|c|c|c|c|c|}
\hline \multirow{2}{*}{ 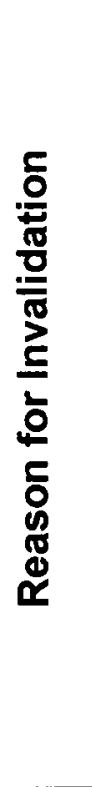 } & 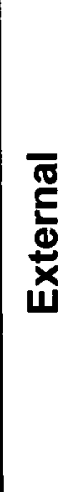 & 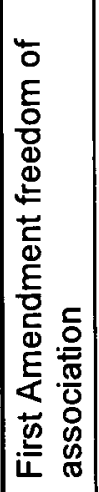 & 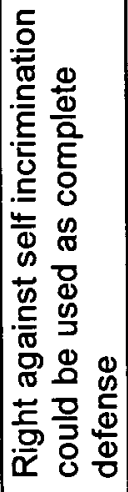 & 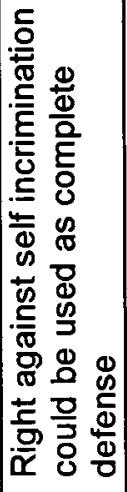 & 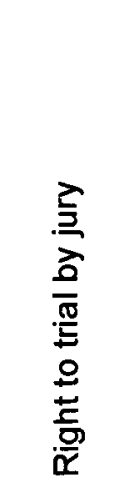 & 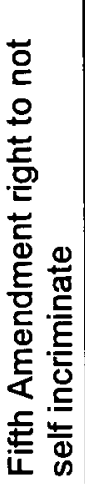 & 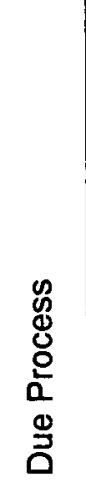 \\
\hline & & & & & & & \\
\hline \multicolumn{2}{|c|}{$\frac{\stackrel{\Phi}{3}}{\underset{D}{\mathbb{D}}}$} & 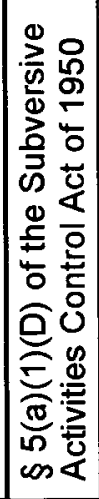 & 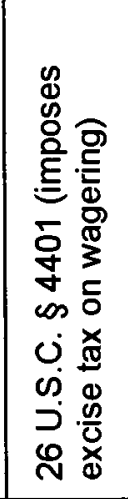 & 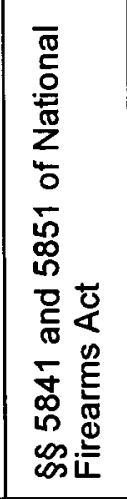 & 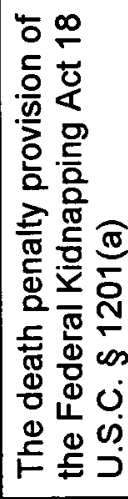 & 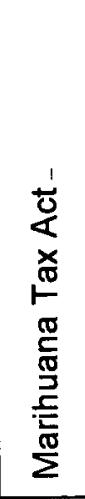 & 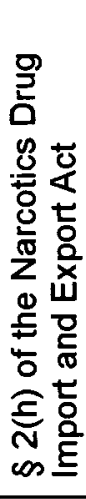 \\
\hline$>$ & & 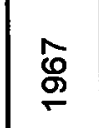 & $\begin{array}{l}\infty \\
\mathscr{8} \\
\stackrel{5}{\circ}\end{array}$ & 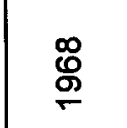 & $\begin{array}{l}\mathscr{0} \\
\stackrel{0}{\circ}\end{array}$ & $\begin{array}{l}\text { : } \\
\stackrel{2}{\circ}\end{array}$ & $\underset{\mathscr{O}}{\stackrel{\mathscr{O}}{\leftarrow}}$ \\
\hline$c$ & & 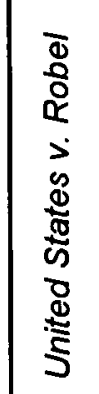 & 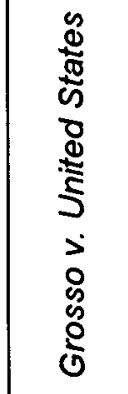 & 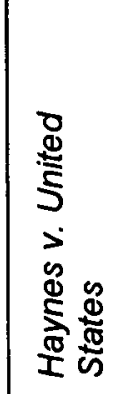 & 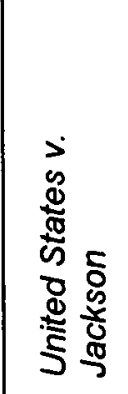 & 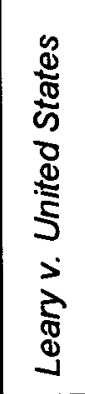 & 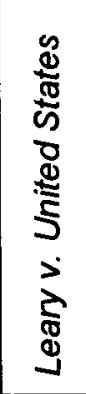 \\
\hline
\end{tabular}




\begin{tabular}{|c|c|c|c|c|c|c|c|c|}
\hline \multirow{2}{*}{ 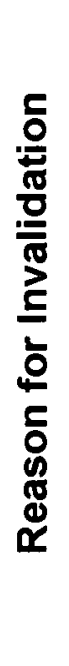 } & 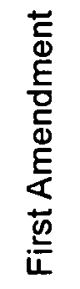 & 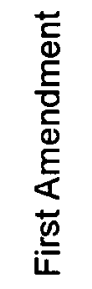 & & & & 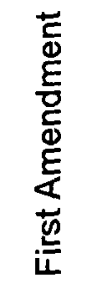 & & 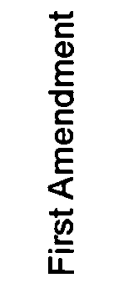 \\
\hline & & & 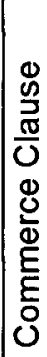 & $\begin{array}{l}02 \\
0 \\
0 \\
0 \\
0 \\
\frac{0}{0} \\
\frac{1}{0} \\
\frac{0}{0} \\
\frac{\pi}{6} \\
0 \\
0 \\
0\end{array}$ & 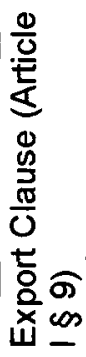 & & 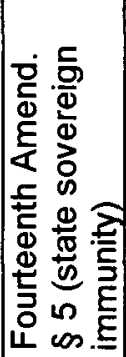 & \\
\hline 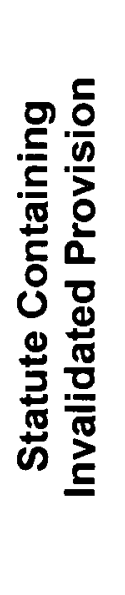 & 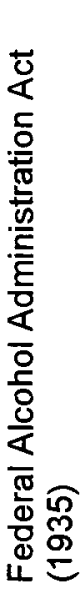 & 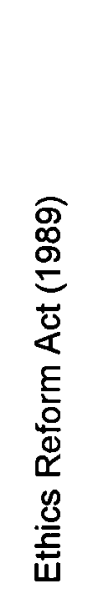 & 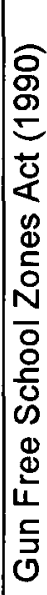 & 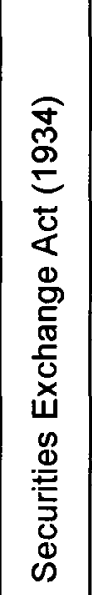 & 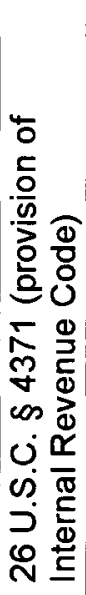 & 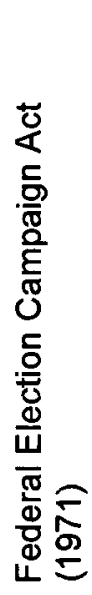 & 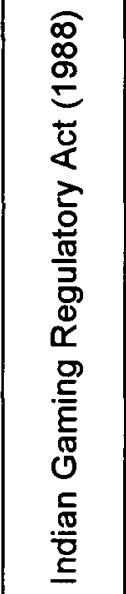 & 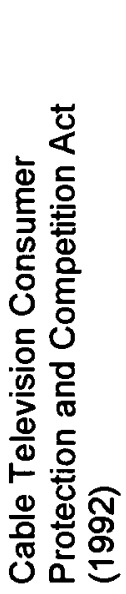 \\
\hline 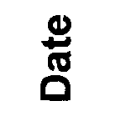 & 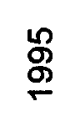 & $\begin{array}{l}\text { م } \\
\text { م } \\
\stackrel{5}{2}\end{array}$ & 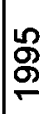 & م & $\begin{array}{l}\stackrel{\circ}{\mathscr{g}} \\
\stackrel{5}{\sigma}\end{array}$ & $\begin{array}{l}\text { g } \\
\text { م }\end{array}$ & $\stackrel{\mathscr{8}}{\circ}$ & $\begin{array}{l}\mathscr{S} \\
\text { क् }\end{array}$ \\
\hline 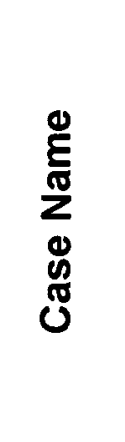 & 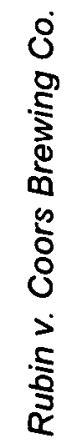 & 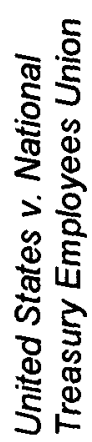 & 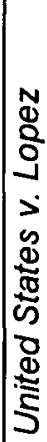 & 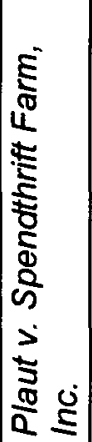 & 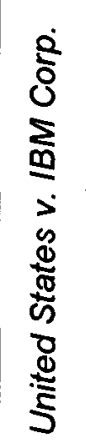 & 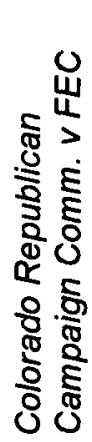 & 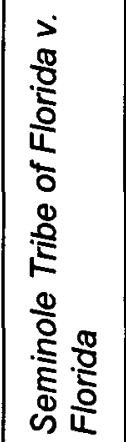 & 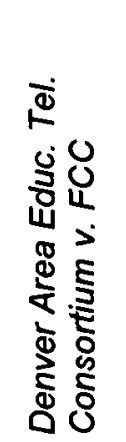 \\
\hline
\end{tabular}




\begin{tabular}{|c|c|c|c|c|c|c|c|c|c|}
\hline \multirow{2}{*}{ 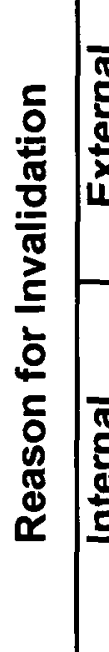 } & 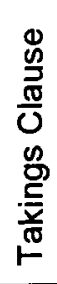 & & 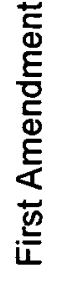 & 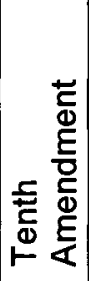 & & 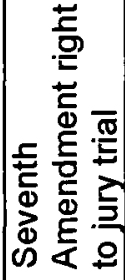 & 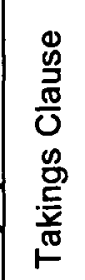 & & 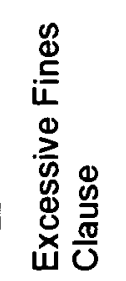 \\
\hline & & 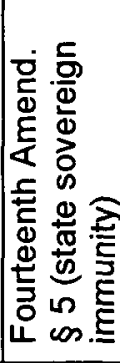 & & & 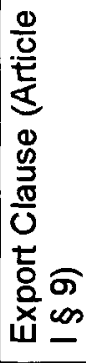 & & & 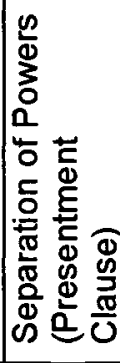 & \\
\hline 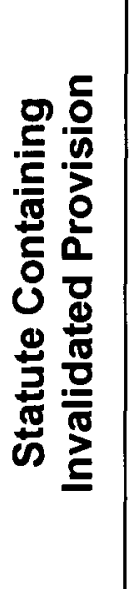 & 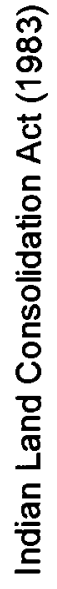 & 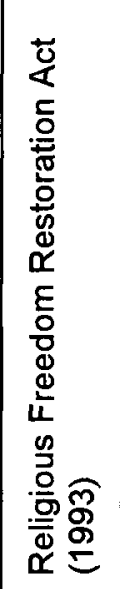 & 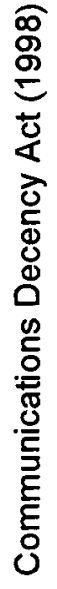 & 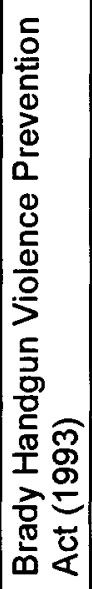 & 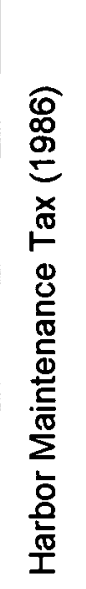 & 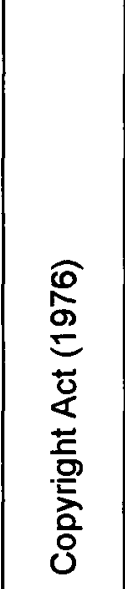 & 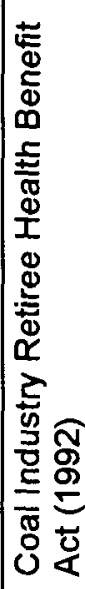 & 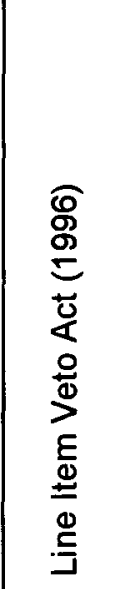 & 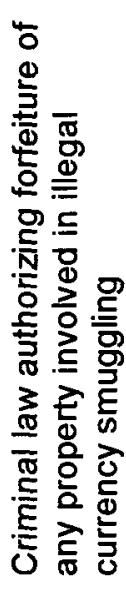 \\
\hline 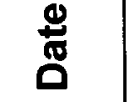 & 용 & कू & م) & 요 & $\begin{array}{l}\stackrel{\infty}{8} \\
\stackrel{9}{\sigma}\end{array}$ & 吕 & $\begin{array}{l}\infty \\
\stackrel{\infty}{\infty} \\
\stackrel{-}{\infty}\end{array}$ & $\stackrel{\infty}{\mathscr{\rho}}$ & $\stackrel{\infty}{\mathscr{\infty}}$ \\
\hline 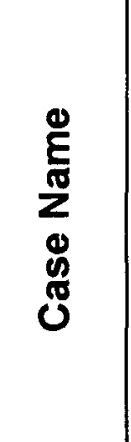 & $\begin{array}{l}0 \\
0 \\
0 \\
3 \\
0 \\
> \\
> \\
\vdots \\
0 \\
0 \\
0 \\
0 \\
0 \\
0\end{array}$ & 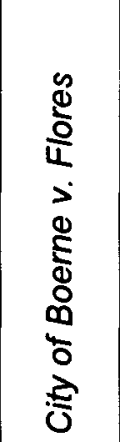 & $\begin{array}{l}\frac{D}{j} \\
0 \\
\frac{1}{0} \\
0 \\
0 \\
0\end{array}$ & 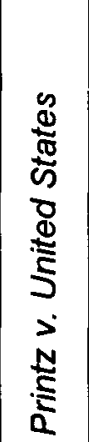 & 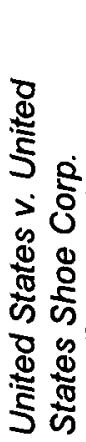 & 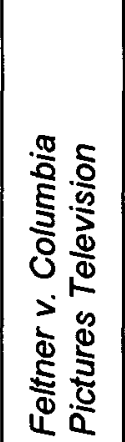 & 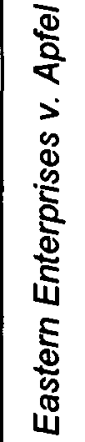 & 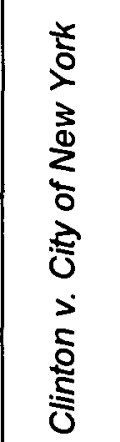 & 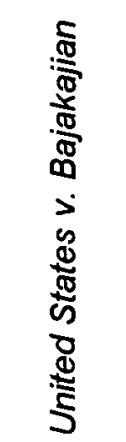 \\
\hline
\end{tabular}




\begin{tabular}{|c|c|c|c|c|c|c|c|c|}
\hline \multirow{2}{*}{ 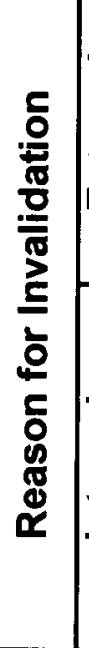 } & 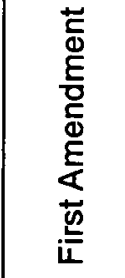 & & & & & & 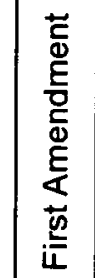 & $\vec{t}$ \\
\hline & & 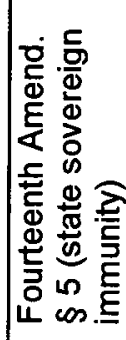 & 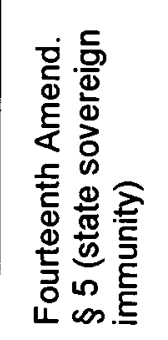 & 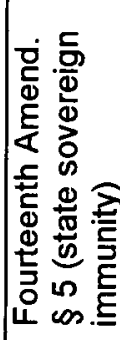 & 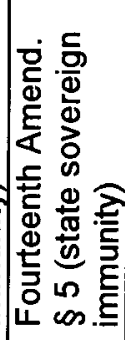 & 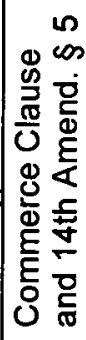 & & $\begin{array}{l}\frac{n}{0} \\
\frac{1}{0} \\
0 \\
\frac{0}{0} \\
\frac{5}{0} \\
\frac{0}{0} \\
\frac{0}{0} \\
\frac{2}{0} \\
\infty\end{array}$ \\
\hline 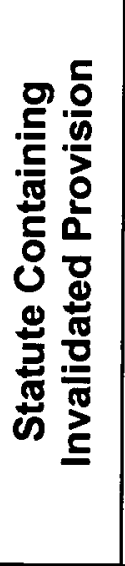 & 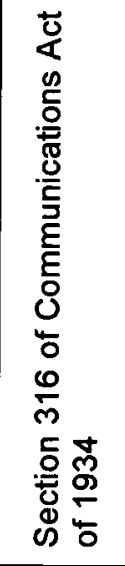 & 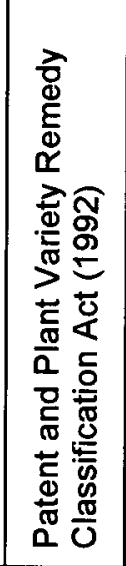 & 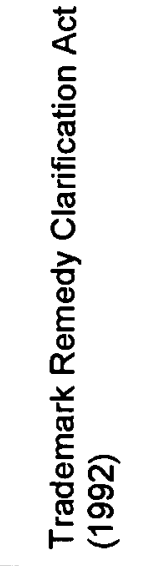 & 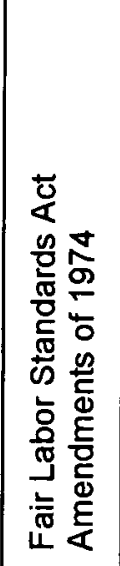 & 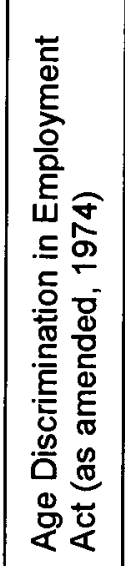 & 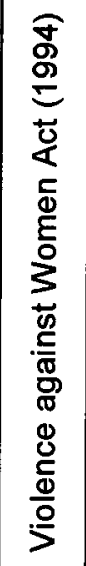 & 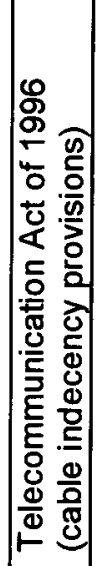 & 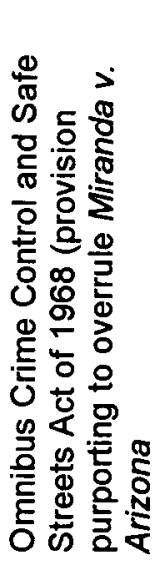 \\
\hline$\underset{\mathbf{D}}{\stackrel{\Phi}{\mathbf{~}}}$ & $\begin{array}{l}\text { \% } \\
\text { o }\end{array}$ & g) & g & \% & 尽 & 용 & 용 & 용 \\
\hline 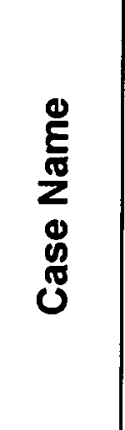 & 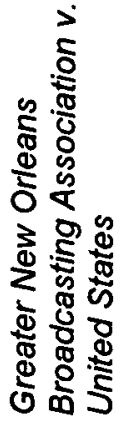 & 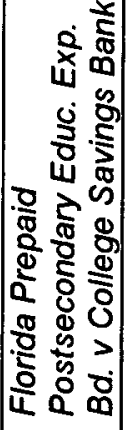 & 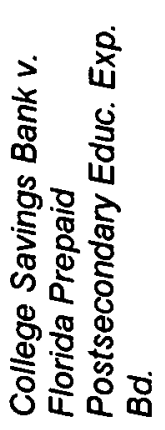 & 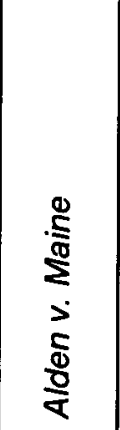 & 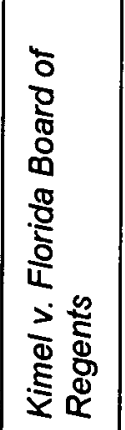 & 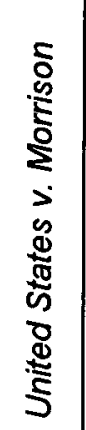 & 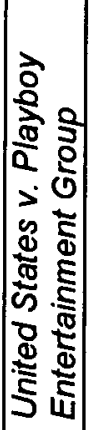 & 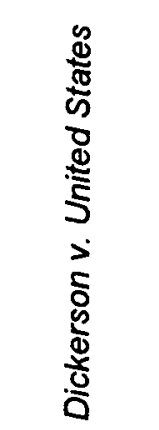 \\
\hline
\end{tabular}




\begin{tabular}{|c|c|c|c|c|c|c|c|}
\hline$\frac{5}{\frac{5}{0}}$ & & 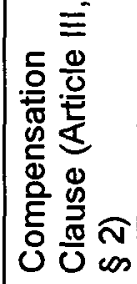 & 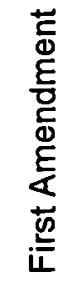 & 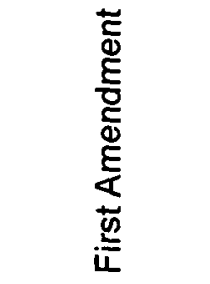 & 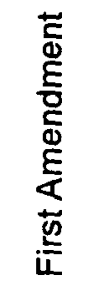 & 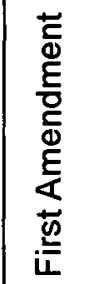 & 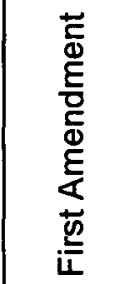 \\
\hline 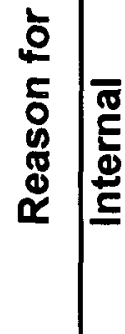 & 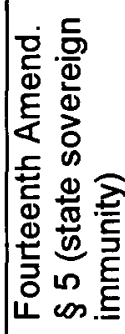 & & & & & & \\
\hline 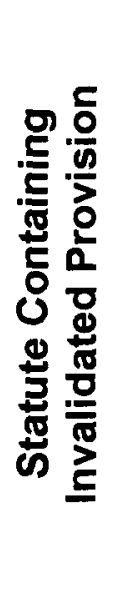 & 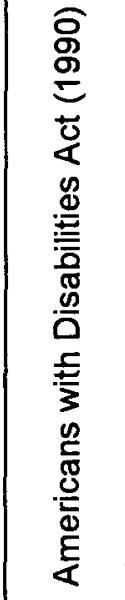 & 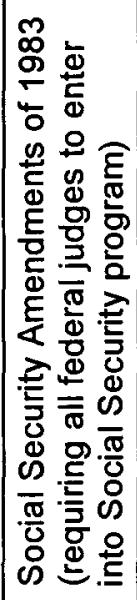 & 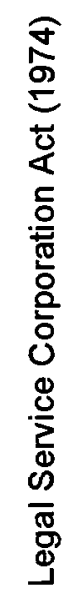 & 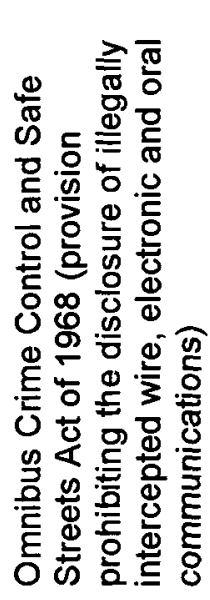 & 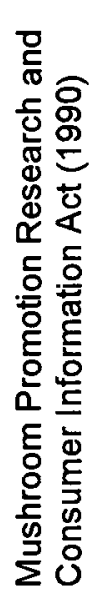 & 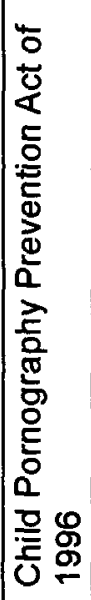 & 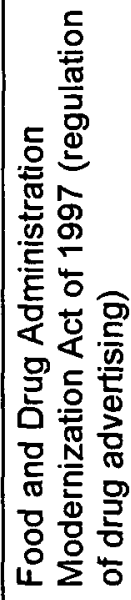 \\
\hline$\underset{\mathbf{0}}{\stackrel{\Phi}{\boldsymbol{D}}}$ & 유 & 유 & ్ㅗㅇ & ర్ల & ్ㅇㅇ & 옹 & 尺̊ \\
\hline 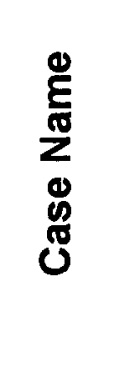 & 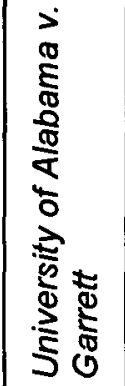 & 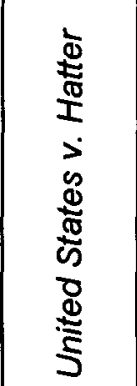 & 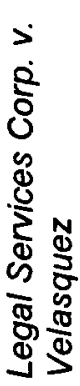 & 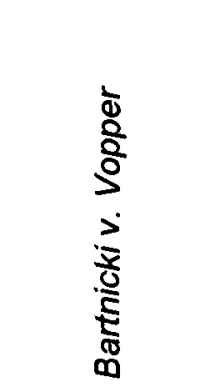 & 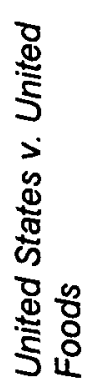 & 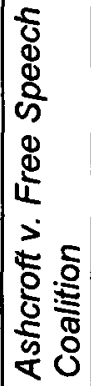 & 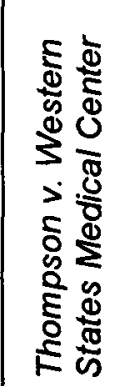 \\
\hline
\end{tabular}


